\title{
Türkiye'nin Sınır Ötesi Göç Politikaları ve Yönetimi
}

\author{
Yllmaz DEMIRHAN ${ }^{1}$ \\ Seyfettin ASLAN ${ }^{2}$
}

Öz: Bu çalışma ana hatlarıyla Türkiye’nin uluslararası göç politikası ve göç yönetimini konu almaktadır. Çalışma öncelikle kavramsal takdimle başlamaktadır. Sonra ana hatlarıyla dünyada göç ve göç yönetimi ile ilgili konular hakkında bilgi verilmektedir. Ardından Türkiye’de göç politikası ve bu politikanın dönüşümüne etki eden faktörler ele alınmaktadır. Ayrıca son otuz yılda iyice yoğunlaşan düzensiz göçler karşısında belirginleşen göç politikası ve bu politikaya yön veren kurumlar ve bu kurumların yetki ve görevleri üzerinde durulmuştur. Bu çerçevede Türkiye'deki hukuksal düzenlemeler ulusal ve uluslararası mevzuat temelinde incelenmiştir. Kurumsal yapılar ise merkezi ve yerel olmak üzere iki düzeyde incelenmiştir. Kurumsal yapılar başlığı altında yerel yönetimlerin de göç yönetimindeki rolü gözden geçirilmiştir. Çalışma, ilgili literatüre dayalı olarak süreç analizi ve betimsel bir yöntemle hazırlanmıştır.

Anahtar Kelimeler: Türkiye, Göç, Göç yönetimi, Göç politikaları.

1 Doç. Dr. Dicle Üniversitesi İİBF Siyaset Bilimi ve Kamu Yönetimi Bölümü, yilmaz. demirhan@dicle.edu.tr

2 Doç. Dr. Dicle Üniversitesi İİB Siyaset Bilimi ve Kamu Yönetimi Bölümü, seyfettinaslan68@gmail.com 


\section{Giriș}

Günümüzde dünyanın pek çok ülkesi için önemli ve çözülmesi zor sorunlardan biri hiç şüphesiz göçtür. Eskiye oranla ulaşım olanaklarının daha iyi olması ve belli bölgelerde süregelen yoksulluk, çatışma, savaş gibi zorunlu itici faktörler ve gelişmiş il, bölge ve ülkelerdeki daha iyi yaşam olanakları, eğitim, sağlık ve iş gibi çekici faktörler her yıl binlerce insanın ülkelerin içinde ve ülkeler arasında yer değiştirmesine sebep olmaktadır. Ancak bu hareketlilik özellikle ulaştığ coğrafyalarda ciddi siyasal, sosyal, kültürel, etnik, dinsel vb pek çok etki ve sorunlara da yol açabilmektedir. Her şeyden önce göç edenler gittikleri yerde yaşayan toplumla uyum sorunları yaşamakta ve göç edenlerin sayısı bir defada çok fazla ise gidilen yerde hemen kabul de görmemektedirler. Şüphesiz bunda göçle gelen nüfusun gida, konut, istihdam, sosyal yaşam ve kültür üzerinde yaptığı veya yapabileceği etkinin payı oldukça büyüktür.

$\mathrm{Bu}$ etkiler göçün yönetilmesi gereksinimini ortaya çıkardığg 1 için uzun zamandan beri ülkelerin bu alanda politika üretmesine, yasal, kurumsal tedbirler almasına da neden olmuştur. Belli dönemlerde göç miktarındaki artış bazı ülkelerin bu politika veya tedbirlerini gözden geçirmesine ya da yeni düzenlemeler yapmalarına yol açabilmektedir.

Göç görünümü itibariyle genel olarak ülkelerin merkezi yönetimlerinin çözmesi gereken bir sorun gibi görünmekle beraber özelde göçten en fazla etkilenenlerin kentler ve kent yönetimleri olduğu söylenebilir. Çünkü göçle gelenlerin öncellikle yerleştikleri yerler kent merkezleri veya çevresi olmaktadır. Bu durum, altyapısı belli bir nüfusa göre düzenlenmiş olan kentlerin yapısını bozmakta, kısa, orta ve uzun vadede yerel idarelere de önemli yük ve sorumluluklar getirmektedir.

Türkiye de göç yolları üzerinde olan bir ülke olarak sürekli göçle yüz yüze kaldığı gibi bazı dönemlerde çevresindeki ülkelerde meydana gelen savaş ve benzeri çatışmalardan kaynaklı kitlesel göçlere de maruz kalmaktadır. Bu göçler genel olarak Türkiye'de özel de ise bazı kentlerde önemli sorunlara yol açmaktadır. Göçten kaynaklanan sorunların 
aşılması için Türkiye de politikalar üretmekte, yasal kurumsal düzenlemeler yapmaktadır.

Yukarıda kısaca özetlenen bilgiler bağlamında bu çalışma Türkiye’nin sınır ötesi göç politikası ve göç yönetimini konu almaktadır. Bu çerçevede önce kısa bir kavramsal çerçeveye yer verilecek, göçün nedenleri, etkileri ve neden yönetilmesi gerektiği hakkında ana hatları ile bilgi verilecektir. Ardından Türkiye'de göç sorunu ve politikasına bakılacak, göçün yönetimi için ülkemizde oluşturulan kurumsal yap1lar ve görevleri üzerinde durulacaktır. Bu kapsamda göçün yönetilmesi için başkentte kurulmuş idari birimler ve görevleri ile yerel idarelerin (merkezi yönetimin taşra idaresi ve belediyelerin) göç yönetimindeki rolleri ele alınacaktır.

\section{Kavramsal Olarak Göç}

Göç, göçmen, sığınmacı ve mülteci gibi kavramlar farklı kişi ve kurumlarca bazı özellikleri ön plana çıkarılarak tanımlanmıştır.

En yalın hali ile göç bir kişinin sürekli olarak yaşadığ yerden ayrılarak coğrafya üzerinde hareket etmesidir. Bir başka anlatımla göç insanların yaşadıkları yerde geçimlerini sağlayamaması gibi şartlara bağlı veya mevcut sosyo-ekonomik politikalara bir tepki nedeniyle bulunduğu yerden diğer alanlara taşınması olarak da tarif edilebilir (Gautam, 2005: 147).

Kişilerin ülke sınırları içinde hareket etmesine iç göç, ülkeler ve k1talar arasında yer değiştirmesine ise dış göç denilmektedir. Sebepleri dikkate alarak bir sınıflandırma yapıldığında gönüllü ve zorunlu olmak üzere iki göç tipi ortaya çıkmaktadır (National Geograpic, 2015). Ayrıca niteliklerine göre işgücü ve beyin göçü (Murat ve Taşkesenlioğlu, 2009:20) ile yasal ve yasadışı göç şeklinde de tasnif yapılabilir.

Çeşitli sebep ve biçimlere bağlı olarak yaşadıkları yeri değiştiren insanlar uluslararası belgelerin ve kurumların tanımlamasına göre mülteci, sığınmacı ve göçmen gibi isimler almaktadırlar. 
Kimlerin mülteci sayılacağı 1951 sayılı Mültecilerin Hukuki Statüsüne İlişkin Cenevre Sözleşmesinde belirtilmiştir. Buna göre mülteci "1rk1, dini, tabiiyeti, belli bir toplumsal gruba mensubiyeti veya siyasi düşünceleri yüzünden, zulme uğrayacağından haklı sebeplerle korktuğu için vatandaşı olduğu ülkenin dışında bulunan ve bu ülkenin korumasindan yararlanamayan ya da söz konusu korku nedeniyle, yararlanmak istemeyen yahut tabiiyeti yoksa ve bu tür olaylar sonucu önceden yaşadığı ikamet ülkesinin dışında bulunan, oraya dönemeyen veya söz konusu korku nedeniyle dönmek istemeyen şahıs"lardır (BMMYK ve İçişleri Bakanlığ 1 2005: 59).

Göçmen ise, genellikle ekonomik veya içinde bulunduğu koşullardan memnun olmaması nedeniyle ülkesini gönüllü bir biçimde terk ederek başka ülkeye yasal veya yasal olmayan yollardan giren kimselerdir. Bunlar mültecilik hakkı ve statüsünden istifade edememektedirler. Mültecilik ile göçmenlik arasında neden, amaç, araç gibi yönlerden farklılık bulunmaktadır. Neden bakımından mülteciler mal varlıklarını geride bırakarak, korku ve yaşamalarına gelebilecek tehditlerden kaçarak güvenli bir ülkeye iltica ederken, göçmenler ekonomik bakımdan rahat etmek için başka ülkeye göç ederler. Dolayısıyla birinde zorunlu diğerinde gönüllü sebepler etkilidir. Mülteciler ve göçmenler yer değiştirme sırasındaki araçları bakımından da farklılaşırlar. Göçmenler genellikle daha uygun araçlarla yer değiştirirken, mülteciler ani kararla yer değiştirdiklerinden daha zor şartlarda ve araçlarla bu eylemi gerçekleştirirler. Göçmenler ülkesinden ayrılıp diğer ülkeye geçerken bazı resmi belgelere sahip iken, mülteciler ise genellikle bu belgelere sahip değillerdir (Ziya, 2012:232-233).

Sığınmacı kavramı da mülteci kavramına çok benzeyen yönlere sahip olup, aynı şekilde 1951 tarihli Cenevre sözleşmesinde belirtilen nedenlerle ülkelerini terk etmek durumunda kalanları tanımladığı halde henüz göç ettikleri ülkenin resmi makamları tarafından kendilerine mültecilik statüsü tanınmamış olan kimseleri ifade etmektedir (Barkın, 2014:335). 


\section{Ana Hatlarıyla Tarihte Göç, Nedenleri, Etkileri ve Göçün Yönetilmesi Gereksinimi}

Tarihin hangi noktasında kaç kişinin göç ettiği, bunların yeryüzüne nasıl dağıldıkları bilinmemekle birlikte tarih öncesinden başlamak üzere dünya genelinde daima küçük veya büyük çaplı insan hareketliliklerin olduğu bilinmektedir. Buna bağlı olarak hiçbir kavim veya ırkın her zaman aynı yerde kaldığı ve hiç değişmeden saflığını koruduğu iddia edilemez. Bilinen en eski kitlesel yer değiştirmelerin başında "Kavimler Göçü” gelmektedir. Doğudan batıya yönelen bu hareket kapsamlı bir demografik, siyasal, sosyal ve kültürel değişime yol açmıştır. Beşyüz yıl önce Avrupalı seyyahların yenidünyalar keşfetmek üzere başlattıkları kıtalararası yolculuklar dünya göç tarihindeki kilometre taşlarından biridir. Bu keşifler neticesinde pek çok kişi Amerika, Asya ve Afrika kıtasına göçmüştür (International Organization for Migration, 2004: 3-15). Sanayileşme sürecine girilmesi ve 16. yüzyıldan itibaren Avrupa’nın dünya siyaseti ve ekonomisinde yükselmesi, sömürgeciliği başlatması, ulus devlet tipinin doğup, yaygınlaşması ardından yayılmacı politikaların artmasıyla göç hareketlerinin de farklı özellikler kazandığı söylenebilir.

Göç tarihinde en önemli duraklarından biri de hiç şüphesiz birinci dünya savaşı ve ardından yaşanan sorunlardır (Çelebi, 2011: 13). Özellikle birinci dünya savaşından sonra birden fazla etnik unsuru bir arada tutan imparatorlukların yıkılmasıyla "çok uluslu kuşak"lar ortadan kalkmış böylece "merkezi despotik bürokrasilerle" imparatorlukların çatısı altında bir arada tutulan bazı etnik gruplar arasında nefret körüklenmiş veya var olan nefret yaygınlaşarak savaşla birlikte istenmeyen etnik grupların zorunlu ve kitlesel olarak başka alanlara göçünü doğurmuştur (Hannah Arendt'en aktaran: Çelebi, 2011: 13).

Elbette ki göç sadece birinci dünya savaşına özgü bir sorun olmamıştır. İkinci dünya savaşı da kitlesel göçe yol açan ve Avrupa kıtasında ciddi bir yıkıma yol açan bir etkiye sahip olmuştur. 
Tarihin belli noktalarında daha fazla ve yoğun şekilde yaşanmış olan göç hala kimi zaman trajik sonuçlara yola açacak şekilde varlığını farklı coğrafyalarda değişen yoğunluklarda sürdürmektedir.

Günümüzde dünyada dördü ana (kuzey-kuzey, güney-güney, güney-kuzey ve kuzey güney) ve yirmisi de bunların içinde olmak üzere çok sayıda büyük göç koridorları bulunmaktadır. İstatistiklere göre göçlerin büyük kısmı güney-güney koridorundan yani orta Asya ülkeleri, Rusya ve Ukrayna çizgisinde olmaktadır (Anich, Brian and Laczko, 2013: 53).

Yukarıda da değinildiği gibi binlerce yıldan beri insanlar çeşitli nedenlerle ülke içinde veya ülkeler hatta kıtalar arasında sürekli olarak yer değiştirmektedirler. Genel olarak bakıldığında bu hareketliliğin birkaç nedeninin olduğu görülmektedir. Bunlar (Laczko ve Anich, 2013: 31-33):

- Ekonomik faktörler (ülkeler arası yaşam koşullarının farklılığı),

- Az gelişmişülkelerdeki zayıf yönetim/yönetişim ve kamu hizmetlerinin yetersizliği,

- Demografik etkenler (gelişmiş ülkelerdeki düşük doğum oranlarının işgücüne gereksinim duyması,

- Az gelişmiş ülkelerdeki yüksek doğum oranlarının ortaya çıkardığı yüksek işsizlik),

- Uluslararası ağlar (daha önce göç etmiş aile üyelerinin diğerlerini de peşinden çekmesi) ve

- Çatışma, savaş ve doğal felaketler şeklinde sıralanabilir.

Dünyada göçlerin hangi nedenlere bağlı olduğu, bunların birey, toplum, devletler açısından ne tür etkiler oluşturduğu bazı teoriler bağlamında incelenmektedir. Genel olarak bu teoriler üç gruba ayrılmaktadır. Birincisi mikro teoriler olup, bireysel göç kararlarını açıklamaya çalışmaktadırlar. Bu grupta yer alan teorilerin başında İtici ve çekici faktörler teorisi, davranışsal modeller ve sosyal sistem teorileri gelmektedir. Bunlar göç nedeni olarak bireysel değerleri, istekleri ve beklentileri 
(daha iyi yaşam, gelir elde etme gibi) göstermektedirler. İkinci gruptakiler orta boy teoriler olarak adlandırılır. Bunlar hane veya toplum düzeyinde göç nedenlerini açıklamaya çalışmakta, sosyal ağlar üzerinde durmaktadırlar. Sosyal sermaye teorisi, kurumsal teori, ağlar teorisi bu grupta yer alır. Son grup teori ise makro olarak adlandırılmaktadır. Bunlar toplam göç eğilimleri üzerine odaklanmakta ve bunları açıklamaya çalışmaktadırlar. Bu grupta yer alan teoriler ekonomik yapı, gelir ve istihdam fırsatları ile farklılıklarını örneklem olarak seçebilmektedirler. Neo Klasik makro göç teorisi, bir sistem olarak göç teorisi, dünya sistemleri teorisi bu grupta yer almaktadır (Zanker, 2008: 5).

Göç nedenleri kadar göçün birey, aile, ülke ve toplumlar üzerinde oluşturduğu etki de önemli olup, bunların ayrıntılı biçimde bilinmesi ve yönetilmesine ihtiyaç duyulmaktadır. Göç ile birlikte başta göç eden bireyler olmak üzere, aileleri, göç veren ve göç alan ülkeler üzerinde sosyal, kültürel, ekonomik, demografik, siyasal, dinsel pek çok etki ortaya çıkmaktadır. Bununla beraber söz konusu göç hareketleri yasa dişı yolarla veya savaş, şiddet vb. nedenlere ortaya çıkmışsa yukarıda sayılan sonuçlara ek olarak büyük sayılara varan ölümler, hastalıklar, kültürel çatışmalar, güvenlik sorunları gibi dramatik etki ve sonuçlar da doğurabilmektedir. Ayrıca ister gönüllü, ister zorunlu olsun bulundukları yerden başka yerlere göç edenler vardıkları yerde işgücü piyasası üzerinde yoğun baskı oluşturarak bu alanda dengenin bozulmasına yol açabilecekleri gibi kamusal hizmetlerden de yeterince istifade edemeyebilirler.

Yukarıda sayılan etki ve sonuçları nedeniyle büyük göç hareketleri günümüzde gelişmiş devletler başta olmak üzere pek çok toplumun önemli ve öncelikli olarak çözmeleri gereken sorunlarından biri haline gelmiş olsa da iyi bir politika ile yönetildiğinde bu hareketlilikler hem göç veren hem alan hem de göç eden bireyler açısından önemli yararlar sağlayabilir. Özellikle gelişmekte olan ülkeler göç yönetimi politikaları ile büyüme, yatırım, beşeri sermaye, yoksulluğun azaltılması vb. konularda yaygın olumlu etkiler oluşturabilirler (Katseli, 2006: 5). 
Etki ve sonuçları ile yönetilme gereksinimi bakımından göç olgusu ve bunun kontrolü daha çok 19. yüzyıldan itibaren ortaya çıkan ve son yüzyılda yaygınlaşan ulus devletler çağında belirginleşmiştir. Bunda ulus devletlerin toprakları üzerinde egemenliklerini pekiştirmesi ve bunun uluslararası kabulü önemli olmuştur. Bu dönemde ulusal sınırlar belirlenmiş ve sınırları geçenler "yurttaş" veya "yabancı" kimlikleri ile kayıt altın alınmaya başlanmıştır. Vize, pasaport, oturma izni gibi göç kontrolü mekanizmaları bu dönemin ürünüdür (İçduygu, Erder ve Gençkaya, 2014: 13).

Ülkelerin göç yönetimi politikalarının iki yönlü olduğu söylenebilir. Birincisi ülke dışına göç verme politikasıdır. Burada amaç dış ülkelerden elde edilecek girdilerle büyüme, kalkınmaya aracılık etmektir. İkinci boyutu ise, göç alma politikasıdır. Bu ek bir yük oluşturduğu için genellikle istenmeyen bir durumdur. Sadece ülkenin ihtiyacı varsa nitelikli işgücü gibi sınırlı bir kesimin ülkeye girişi arzulanır. Onun dışındaki göç sıkı denetimle kontrol altında tutulmaya çalışılmaktadır. Ülkelerin göç yönetimi de büyük ölçüde ikinci boyut üzerinde yoğunlaşmaktadır.

Birinci dünya savaşının sonuna kadar ulusal çabalarla yönetilmeye çalışılan göç sorunu bundan sonra küresel kuruluşların da ilgi alanına girmeye başlamıştır. Bu çerçevede 1920-30 arasında Milletler Cemiyeti sorunun tartışılması ve kalıcı çözüme ulaştırılması için bir takım eylemlerde bulunmuştur. İkinci dünya savaşı döneminde Hükümetler arası Mülteci Komitesi kurulmuştur. Bu komitenin görevi daha çok Almanya ve Avusturya' dan kaçanlara yeni yerleşim yerleri bulmak ve onları rehabilite etmekti. Bu oluşumu Birleşmiş Milletler Yardım ve Rehabilitasyon İdaresi takip etti. 1946'da Birleşmiş Milletler Genel Kurulu Uluslararası Mülteci Örgütü Anayasasını kabul etti. 1951'de Birleşmiş Milletler Mülteci Örgütü yerini Birleşmiş Milletler Mülteciler Yüksek Komiserliğine $^{3}$ (UNHCR- The United Nations Refugee Agency) biraktı (International Organization for Migration, 2004: 18).

3 BM Mülteciler Yüksek Komiserliği dünyanın çeşitli bölgelerindeki mülteci sorunlarını çözmek ve mültecileri korumak amacıyla uluslararası faaliyetleri koordine görevini yürütmektedir. Komiserlik her bireyin sığınma talebinde bulunabilmesini, başka bir ülkede sığınmacı olarak barınabilmesini, sağlamaya çalışmaktadır. Ayrıca 
İzleyen yıllarda uluslararası göç sorunlarını çözmek, bu yönde politikalar geliştirmek üzere başka küresel kuruluşlar da tesis edildi. İkinci dünya savaşının ardından hükümetler arası bir organ olarak Avrupa'da ortaya çıkan ve 1989 adı Uluslararası Göç Örgütü4 ile 1993’te Avusturya ve İsviçre öncülüğünde kurulan Uluslararası Göç Politikaları Merkezi ${ }^{5}$ bu kuruluşların önemlilerindendir.

Göç sorunu ve buna devletler üstü politika üreten küresel kuruluşlar içinde Türkiye'yi de doğrudan etkilemesi bakımından Avrupa Birliği (AB) önemli bir yer tutmaktadır. Temelleri 1950'li yıllarda atılan ve 1992'de Maastricht Antlaşması ile sınırların kalktığı siyasi ve ekonomik bir örgüt halini alan $\mathrm{AB}$ pek çok konu gibi göç alanında da düzenleme yapmış ve politikalar üretmiştir.

gönüllü eve dönüş, yerel uyum ve üçüncü ülkelere yerleştirilme seçeneklerini de mültecilere sağlamaya çalışmaktadır. Kuruluşun görev alanı içinde vatansız kişiler de bulunmaktadır. Kuruluş 2015 yılı itibariyle 9.300 ulusal ve uluslararası çalışanı ile 125 ülkede faaliyet yürütmektedir. 2015 yılı bütçesi 6.8 milyar ABD dolarıdır. Dünya genelinde yaklaşık 51 milyon kişi çeşitli sebeplerle yerinden sökülmüştür. Komiserliğin ilgilendiği kişi sayısı ise 42.9 milyondur. Bunların 23.9 milyonu içeride yerinden olmuş kişiler, 11.7 milyonu mülteci, 1.8 milyonu geri dönenler, 3.5 milyonu vatansızlar, 1.2 milyonu sığınmacılar ve 836 bini diğer kişilerden oluşmaktadır (UNHCR, 2015).

4 Uluslararası Göç Örgütü 2. Dünya savaşından sonra hükümetler arası bir organ olarak Avrupa'da ortaya çıkan göç hareketleri ile ilgili olarak kurulmuştur. 1989'a kadar kapsam alanı değiştikçe adı da değişikliğe uğramış ve o tarihte Uluslar arası Göç Örgütü adını almıştır. Dünya Göç Örgütü günümüzde Türkiye’nin de aralarında yer aldığı 150 üye ülke, 10 gözlemci ülke, 1.3 milyar dolar bütçesi ve 150 ülkeye yayılmış 8.400 çalışanı ile büyük bir küresel örgüt halini almıştır. Günümüzde küresel düzeyde göç ile ilgili olarak insani yardım programları, göçmen sağlığı, eğitimi, insan ticaretini engelleme, göç hukuku, göçmen uyumu, göç ve sınır yönetimi, göç politikaları ve araştırmaları ile göç ve kalkınma gibi konularda faaliyet sürdürmektedir (http://www. iom.int/cms/en/sites/iom/home/about-iom-1/history.html).

5 Uluslararası Göç Politikaları Geliştirme Merkezi (International Centre for Migration Policy Development/ICMPD) 1993 yılında Avusturya ve İsviçre’nin öncülügüünde kurulmuş olup, Birleşmiş Milletler (BM) gözlemci statüsüne sahiptir. Merkez, göç politikalarıyla ilgilenen Hükümetler veya Hükümetler üstü kuruluşlara kısa ve uzun vadede projeler üretmektedir. Merkezin amacı, yenilikçi, kapsamlı ve sürdürülebilir göç politikalarını teşvik etmektir. Üye Ülkeler; Avusturya, Bosna-Hersek, Bulgaristan, Hırvatistan, Çek Cumhuriyeti, Macaristan, Makedonya, Polonya, Portekiz, Romanya, Sırbistan, Slovakya, Slovenya, İsveç ve İsviçre (Göç İdaresi Genel Müdürlüğü, 2015). 
AB’nin göçe yaklaşımı dönemler itibariyle değişiklikler göstermektedir. AB açısından ilk dönem aslında daha sonra AB'yi oluşturacak ülkelerin ikinci dünya savaşı sonrası yeniden imar için ihtiyaç duyulan işgücü göçünü ifade etmektedir. Bu dönem 1973’teki petrol krizine kadar devam etmiştir. Bu tarihten itibaren AB'nin göç politikası değişmeye başlamıştır. Bir yandan ekonomik nedenler diğer taraftan AB'ye yönelik yoğun göç bu alanda bir paradigma değişikliği ile sonuçlanmıştır. Yeni dönemin 1975’te Roma Zirvesinde üye devletlerin içişleri ve adalet bakanlarının katılımıyla oluşturulan ve amacı sivil havacılık güvenliği, nükleer güvenlik ile terörizm konularını görüşmek olan Tirevi Grup adlı örgütün kurulmasıyla başladığı söylenebilir (ORSAM, 2012: 12-13). Sonraki yıllarda $A B$ göç politikası daha belirgin bir hal almıştır. AB bir yandan günden güne sınırları kaldırılmış, ekonomik bakımdan bütünleşmiş bir Avrupa için üye ülke vatandaşlarının birlik içinde serbest dolaşımını Schengen vb. antlaşmalarla sağlamaya çalışırken diğer yandan 1970’li yıllara kadar göç etmiş olanları AB toplumuyla bütünleştirme yönünde adımlar atmıştır. Bununla beraber 1990’lı yılların sonundan itibaren mülteci ve iltica konularında ulus üstü bir yönetişim yaklaşımıyla ortak bir AB politikası geliştirmeye çalışılmıştır. Bu çerçevede 2001'de Geçici Koruma Direktifi düzenlemesi yapılmış, Avrupa Mülteci Fonu oluşturulmuş, Avrupa Sınır Güvenliği Ajansı (FRONTEX) kurulmuştur (Tolay, 2014; Murat ve Taşkesenlioğlu, 2009: 72). Nihai düzenleme ise 2013 yılında Avrupa Birliği Sığınma Sistemi (CEAS)' ile olmuştur. Beş ana belgeden oluşan CEAŞ’ın amacı üye ülkelerin sığınma politikalarını standart hale getirme, AB içinde işbirliğini arttırma, birlik ülkeleri arasında sorumlulukları adil dağıtma ve mültecilere yüksek koruma standartları sunmaktır (Tolay, 2014).

Avrupa Birliği, sınırları içinde aldığı tedbirler, yaptığı düzenlemelerle mültecilerin üye ülkelere girişini kısıtlamanın dışında göç ve iltica taleplerini kaynağında çözmek için bazı ülkelerle işbirliğine gitmekte, onlara teknik ve maddi bazı yardımlarda bulunmakta (Murat ve Taşkesenlioğlu, 2009: 57-72) ve yoğun göç aldığ 1 ya da göçün geçiş 
noktasında yer alan ülkelerle geri kabul antlaşmaları yapmaktadır. Bu antlaşmalar kişileri göç ettikleri veya en son ayrıldıkları ülkelere iade etmeyi içeriyor. 2001-2008 arasında Makedonya, Arnavutluk, Bosna-Hersek, Hong-Kong, Macao, Moldova, Rusya, Surbistan, Sri-Lanka ve Ukrayna ile yapılmıştır. Aynı şekilde Çin, Pakistan, Cezayir ve Fas ile de bu antlaşmaların yapılması için çalışmalar yapılmaktadır. Türkiye de bu amaçla müzakerelerin yürütüldüğü ve tamamlandığı ülkelerden biridir. Türkiye sözleşmeyi 2014'te kabul etmiştir. AB’nin bu alanda son 20-30 yılda yaptığı düzenlemeler daha güvenlikçi bir çizgiye kaymıştır.

Göç ile mücadele konusunda ulusal ve ulus üstü örgütlerin çabalarının yanı sıra küresel düzeyde göç yönetimi politikalarına kaynaklık edebilecek bazı düzenleyici metinler de uluslararası kuruluşlarca özelde üye ülkelerde genelde ise dünyada uygulanmak üzere kabul edilmiştir. $\mathrm{Bu}$ düzenleyici metinlerin başında 1951'de Cenevre'de imzalanan Birleşmiş Milletler Mülteci Hakları Sözleşmesi ve 1967'deki ek protokolü gelmektedir. Bu sözleşme kimlerin mülteci olarak kabul edileceği, mültecilerin hakları gibi konularda temel ilkeleri ortaya koymuştur. Daha sonra bu sözleşmeyi esas alarak 1969'da Afrika Birliği Örgütü Afrika'daki Mültecilerin Bazı Sorunlarının İyileştirilmesine Dair Sözleşmeyi kabul etmiş, 1984'te ise Latin Amerika hükümetleri temsilcileri ile hukukçular Cartagena Deklerasyonu'nu ilan etmişlerdir (International Organization for Migration, 2004:9).

Avrupa İnsan Hakları Sözleşmesi, Birleşmiş Milletler Tüm Göçmen İşçilerin ve Aile Fertlerinin Haklarının Korunmasına Dair Uluslararası Sözleşme, Göçmen İşçinin Hukuki Statüsü Hakkında Avrupa Sözleşmesi, Mültecilerin Hukuki Durumuna İlişkin Sözleşme, İnsan Hakları Evrensel Bildirgesi, Uluslararası Çalışma Örgütü’nün 143 sayılı Kötü Koşullarda Çalışan Göçmen İşçilere Fırsat Eşitliğini Sağlama ve Haklarını İyileştirme Sözleşmesi, Avrupa Konseyi’nin Yabancıların Yerel Kamusal Yaşama Katılımı Sözleşmesi de bu konuda düzenlemeler içeren diğer uluslararası metinlerdir (Tapia, 2006: 41; Göç İdaresi, 2015). 


\section{Sınır Ötesi Göç ve Türkiye}

Göç hareketleri günümüzde daha çok gelişmiş batı ülkelerine yönelik görünmekle beraber Türkiye'yi de oldukça etkileyen bir sorundur. Türkiye devamı olduğu Osmanlı devletinden beri çeşitli göç hareketleri ile yüz yüze kalan ve bu kapsamda milyonlarca insana ev sahipliği yapan bir ülke olmuştur.

Cumhuriyetin ilanından itibaren Türkiye’nin karşı karşıya kaldığ sınır ötesi göç olgusu uluslararası korumaya muhtaç olanlar (mülteci ve sığınmacılar), düzenli göçmenler (işadamı, öğrenci vb) ile düzensiz göçmenler (yasadışı ve kaçak yollarla ülkeye giriş yapanlar) şeklinde temelde üç gruba ayrılmaktadır (Kalkınma Bakanlığı, 2014: xiii-1).

Cumhuriyetin kuruluşundan (hatta Osmanlıdan) beri Türkiye'nin en çok karşılaştığı göç türü uluslararası korumaya muhtaç mülteci ve sığınmacı gruplardan oluşmaktadır. Bu duruma Osmanlı (döneminin büyük devletlerinden biri olması) ve Türkiye’nin (jeopolitik bir coğrafyada yer alma, göç edenlerle yakın dinsel, siyasal ve kültürel bağlara sahip olma vb.) öznel bazı koşulları kadar göçe kaynaklık eden ülkelerde yaşanan çeşitli sorunların da büyük etkisinin olduğu söylenebilir.

$\mathrm{Bu}$ yönüyle bakıldığında Osmanlı devletindeki göçlerin geçmişi 14. yüzyıla kadar geriye gitmektedir. Bu dönemde Osmanlı topraklarına yönelen göçlerin bir kısmı küçük gruplardan oluşurken (Bavyera' dan gelen Aşkenaz Yahudileri gibi) bir kısım göçler ise daha büyük nüfusları barındırmaktaydı. Bunlara örnek olarak 1492'de İspanya'dan kaçan yaklaşık yüz bin kişilik Seferad Yahudileri, 19. yüzyıldaki milliyetçi ayaklanmalar sırasında Habsburg Hanedanlığından kaçıp gelen mülteciler ve Ruslar'dan kaçan yaklaşık bir milyon Çerkez gösterilebilir (Kirişçi, 2003). Görüldügü gibi Osmanlı bir bakıma açık kapı politikası uygulayarak kendisine sığınanları ülkesine kabul etmiştir.

Osmanlı’nın yıkılışı ve cumhuriyetin kurulması ile birlikte Müslüman Arnavutlar, Bosnalılar, Pomaklar ve benzeri Türk soyundan gelen diğer gruplar Anadolu'ya gelmiş, Hıristiyan din mensupları ve Avrupa'da 
Alman işgalinden kaçan yaklaşık yüz bin Yahudi’nin göç ettiği ülke Türkiye olmuştur. Yine İsrail Filistin savaşından kaçan Filistinliler, ikinci dünya savaşında Nazilerin Balkanları işgali üzerine Bulgaristan'daki Müslümanlar, Türkler, Ege'den Yunanlılar ve On iki Adalardan göç eden İtalyan'lar Türkiye’ye sığınmışlardır (Kirişçi, 2003).

1980'li yıllardan itibaren Türkiye komşusu İran, Sovyet Sosyalist Cumhuriyetler Birliği, Irak, Suriye gibi ülkelerde meydana gelen bölünmeler, siyasi krizler, rejim değiş̧iklikleri ve iç çatışmalar nedeniyle bu ülkelerden yeni ve yoğun göç dalgaları ile karşı karşıya kalmıştır (İçduygu, 2014: 53-58).

Göç İdaresine göre 1922-2013 tarihleri arasında farklı ülke, etnik, din ve mezheplerden yaklaşık bir buçuk milyon kişi Türkiye’ye göç etmiştir. 2011'de Suriye'de baş gösteren iç savaş nedeniyle Türkiye'ye ye sığınan yaklaşık 1.760 milyon kişi de eklendiğinde bu sayı toplamda yaklaşık 3 milyona ulaşmaktadır. Göç ile değişik tarihlerde Türkiye'ye gelenlerin bir kısmı daha sonraki yıllarda Türkiye'den ayrılmışken, büyük bölümü Suriyelilerden oluşan önemli bir nüfus ise hala ülkemizde yaşamaya devam etmektedir.

Mülteci veya Sığınmacı olarak nitelendirilen bu kitlesel hareketlerin yanı sıra 1990'lı yıllarda Türkiye düzensiz göç olarak adlandırılan ikinci bir göç türü ile tanışmıştır. İlgili yazında belgesiz, kaçak, yasa dışı gibi bazı tanımlamalarla ifade edilen bu göç şekli kişilerin ülkelere yasa dışı yollarla girişini veya izin ve ikamet sürelerinin aşılarak hukuksuz biçimde bir ülkede kalmaya devam etmeyle ifade edilmektedir. Türkiye'ye bu şekilde giriş yapanların çoğu aslında başta Avrupa'dakiler olmak üzere başka ülkelere geçme amacı taşımaktadır. Türkiye topraklarının aracı veya kısa süreli olarak kullanıldığı bu durum özellikle Türkiye ve $\mathrm{AB}$ arasında bazı sorunlara ve eleştirilere de kaynaklık ettiğinden yetkili makamlarla göçmenler arasında gerilimlere de neden olmaktadır.

Göç İdaresi verilerine göre Türkiye'ye kaçak yollarla girmeye çal1şırken yakalanan göçmenlerin sayısı 1998'de 29.426 iken, 2000 yılında 
94.514'e ç1kmış sonraki yıllarda azalarak 2014'te 58.647'ye düşmüştür. 1998-2014 döneminde yakalanan toplam kişi sayısı ise 961.000 'dir. Bu kişiler genellikle Suriye, Irak, İran, Afganistan, Pakistan, Eritre, Myanmar, Gürcistan, Azerbaycan (Göç İdaresi, 2015) ve Afrika ülkelerinden gelmektedir.

Bunların dışında Türkiye düzenli veya yasal şekilde de yabancıların göç ettiği bir ülkedir. Düzenli göç yasalarla belirlenen çerçevede yurtdışından ülkeye gelen insan hareketlerini içermektedir. Düzenli göç kapsamında, göçmenlerin Türkiye sınırları içinde yasalara uygun şekilde bulunması için giriş izni ile çalışma ve/veya oturma izinlerini almış olması gerekmektedir. Düzenli göç akımları birbirini dışlamayan üç temel amaç doğrultusunda gerçekleşmektedir: Bunlar çalışma, eğitim ve yaşamak için yerleşme şeklindedir. Bu kapsamda 2000-2011 döneminde yaklaşık 2 milyon kişi oturma izni almıştır. Düzenli göçmenlerin \% 28'i çalışmak ve eğitim almak için Türkiye'de bulunmaktadır. Geriye kalan kısım ise yaşama eksenli sebeplerden ötürü oturma izinlerini almıştır (Kalkınma Bakanlığı, 2014: 11). Göç İdaresi verilerine göre 2014 yılı içinde ikamet izni verilenlerin sayısı yaklaşı 380 bin kişidir.

\section{Türkiye’nin Göç Politikaları ve Yönetimi}

Kendisine yönelen kitlesel göç hareketleri karşısında Türkiye’nin nasıl bir politika izlediği sorusu pek çok yazar tarafından modern-ulus devlet ve uluslararası ilişkiler bağlamında bir tasnif yapılarak cevaplanmıştır. İç duygu da konuya bu bağlamda yaklaşan yazarlardan biri olarak, göç politikalarını üç döneme ayırmaktadır. Ona göre birinci dönem 1923-1950 yıllarını kapsayan ulus-devlet inşasının erken dönemidir. İkincisi, 1950-1980 yılları arasındaki ulus-devlet inşasının (ve korunmasının) 'yerel' ve 'ulusal' olarak yerleşik hale geldiği süreçtir. Sonuncusu ise, 1980 yılından bu yana, ulus-devlet inşasının (ve korunmasının) 'küresel' olarak belirginleştiği aşamadır. Yazar bu üçlü ayrımın genelde 
Türkiye'nin ekonomik, toplumsal ve siyasal tarihinin dönemlere ayrılması ile de benzerlik gösterdiğini belirtmektedir (İç duygu, 2014: 53).

İlk dönem göç politikası ulus devlet inşasına hizmet eden bir anlayışla nüfusun hızla etnik, dini ve kültürel yönden türdeş hale getirilmesini esas almıştır. Bu amaçla Türkiye'nin kuruluşu ile birlikte hatta biraz daha öncesinde ülkeden bazı azınlıkların gönderilmesi yerine de Türk, Müslüman ve Türk kültüründen olanların getirilmesi yoluna gidilmiştir (Okutan, 2009; Aktar, 2012). İlerleyen yıllarda daha fazla benimsenen bu politika ile gayrimüslimlerin Türkiye'den Müslüman ve soydaş olanların ise Türkiye'ye göçü kurumsallaşmıştır. Böylece siyasa yapıcılar yürüttükleri göç ve iskân politikaları ile bir taraftan az olan Türkiye nüfusunu arttırmaya çalışırken diğer taraftan saf bir Türk nüfus oluşturmaya çalışmışlardır (İçduygu, Sert ve Karaçay, 2009: 1).

Bu çerçevede 30 Ocak 1923’te Yunanistan ile yapılan “Türk ve Rum Nüfus Mübadelesine İlişkin Sözleşme ve Protokol”e binaen Türkiye’de yerleşik olan Rum Ortodoks Dininden Türk uyrukları ile Yunanistan'da yerleşik Müslüman dininden Yunan uyrukları istisnalar dışında (İstanbul'da oturan Rumlar ve Batı Trakya' da oturan Türkler gibi) mübadeleye tabi tutulmuşlardır (Okutan, 2009: 227-228). Mübadele ile yaklaşık olarak 1 milyon 200 bin Anadolu Rum'u Türkiye'den ayrılmış, 400 bin Rumeli Müslüman’ı Türkiye’ye gelmiştir (Aktar, 2012: 32).

Bununla birlikte cumhuriyetin başlarında yapılan bazı hukuki düzenlemeler de bu nüfus saflaştırma hedefine hizmet etmiştir. 1934'te çıkarılan İskân Kanunu bu işlevi belki de en fazla yerine getiren yasal düzenlemedir. Kanun çıktığg tarihten itibaren Türk soyu ve kültürüne yakın olanların sığınmacı ve mülteci olarak alımını kolaylaştırırken, böyle olmayanların ülkeye girişini ise sınırlandırmıştır. Ayrıca kanunla ülke içinde bulunup Türk olmayanların da Türkleşmesini sağlamak için belli bölgelere yerleştirilmelerine imkân sağlamış ve Türkleştirme süreci bu yolla tamamlanmaya çalışılmıştır. 2006 'da yenilenen kanun hala benzer bir içeriğe sahiptir (İç duygu, 2014: 53-58). İskan Kanunu’nun 
yanı sıra 1924 Anayasası'nın 92. maddesi ve 1926'da çıkarılan cumhuriyet döneminin ilk memur kanunu (788 Sayılı Memurin Kanunu madde 4) ile devlet memuriyeti Türklere has kılınmıştır. O dönemde çıkarılan diğer yasal düzenlemelerle bazı mesleklerin yapılması hakkı sadece Türkiye Cumhuriyeti vatandaşlarına tanınmış, ticaret millileştirilmeye çalışılmıştır. Varlık Vergisi ile gayri Müslimler için yeni yaptırımlar ortaya çıkmıştır (Aktar, 2012: 113-135).

Cumhuriyetin başından itibaren yürütülen nüfusun saflaştırılma politikasının ve bu amaçla yapılan yasal düzenlemelerle diğer bazı nedenler dikkate alındığında yürütülen politikanın sonuç verdiği söylenebilir. Çünkü 1914 Rum ve 1915 Ermeni Tehcirleri, 1923 nüfus Mübadelesi, 1948'de İsrail'in kuruluşu, 6-7 Eylül 1955 olayları ve 1964 Kıbris Rum bunalımına bağlı olarak Osmanlı’nın son yıllarından 1965’e kadar yaklaşık olarak iki milyon azınlığın Türkiye'den ayrıldığı tahmin edilmektedir (Okutan, 2009: 238-239).

1950-80 yılları arasını kapsayan ikinci dönem Türkiye'de ulus-devlet inşasının yerel olarak yerleşik bir boyut kazanması aşamasıdır. $\mathrm{Bu}$ dönemde Türkiye'nin sanayileşme sürecine girmesiyle kırdan kente bir göç hareketi başlamıştır. Bununla birlikte Müslüman olmayanların ülke dışına göçü çeşitli nedenlerle devam etmiştir. Aynı dönemde özellikle Yugoslavya ve Bulgaristan'dan Türkiye’ye Türk kökenli olanların göçü sürmüştür. Dönemin diğer özelliği 1960’lı yıllardan itibaren ilk kez Türkiye'den çalışma amacı ile batı ülkelerine yoğun bir göçün başlamış olmasıdır. Döviz girdisi sağlamak, ekonomiye katkı sunmak üzere başta Almanya olmak üzere Avrupa ülkelerine verilen yoğun göç bu kapsamdadır. Bu dönemin bir diğer özelliği1980'li yıllarda Türkiye'ye sınırı olan ülkelerde meydana gelen iç karışıklıklar, rejim değişiklikleri vb. nedenlerle göçün başka bir boyutu ile karşılaşılmış olmasıdır. Böylece ilk kez Türk ve Müslüman olmayanlardan Türkiye’ye göç gerçeklemiştir (İçduygu, 2014: 53-58).

Türkiye bu dönemde özellikle ülkeye yönelik göçü küresel bazı kuruluşların çıkardığı bir kısım metinleri esas alarak yönetmiş ve politika 
geliştirmeye çalışmıştır. Bu amaçla mültecilerin uluslararası hukuktaki konumunu tanımlayan 1951 tarihli Cenevre Sözleşmesi coğrafi sınırlama şartı konularak 1961'de 359 sayılı kanunla kabul edilmiştir. Hala coğrafi sınırlama kaydı ile yürürlükte olan bu antlaşma ile sadece Avrupa Konseyi üyesi ve eski Sovyetler Birliği içinde yer alan ülkelerden kaynaklı mültecilerin iltica başvurusu değerlendirilmeye alınmaktadır. Bu durum, uluslararası mülteci sisteminde göreceli olarak yüksek hacimde mülteci hareketlerine kaynaklık eden Asya, Ortadoğu ve Kuzey Afrika ülkelerinden yapılacak başvuruların önünü kesmiştir (Kalkınma Bakanlığı, 2014: 25).

1980’li yıllardan günümüze hem Türkiye’nin karşılaştığı göç türü değişmiş hem de Avrupa Birliğỉne üyelik sürecinin etkisiyle bu alandaki politika ve kurumsal düzenlemeler de daha belirgin bir hal almıştır. Yukarıda da belirtildiği gibi 1980 yıllarda başlayıp, hala devam eden çevre ülkelerdeki karışıklık ve rejim sorunları insanları kitlesel halde Türkiye'ye yönlendirirken aynı zamanda 1990'lı yıllarda küreselleşmenin hız kazanması ile ülkeler arası geçişler eskiye oranla fazlasıyla artmıştır. Birçoğu ülkelerindeki geçim, sosyal ve kamusal hizmetlerin eksikliğinden kaynaklanan sebeplerden başlayan bu yeni ve yoğun göç hareketlerinin yönü Avrupa ve diğer gelişmiş bölgeler olduğundan bu bölgelere sınır olan ülkeler de ciddi şekilde etkilenmiştir. Bu nedenle son 20-25 yıldır özellikle Afrika ve Asya kökenli pek çok kişi çoğunlukla yasa dışı yollarla Türkiye'yi kullanarak Avrupa'ya geçmeye çalışmıştır.

Sayıca fazla olan bu kişilerin Türkiye'ye girişleri, kalışları ve statüleri pek çok sorunlara neden olmuştur. Çünkü Türkiye’nin 1951 tarihli Cenevre Sözleşmesi ile koymuş olduğu coğrafi alan sınırlaması dışında kalan ülkelerden gelenler sözleşme harici mülteciler olarak kabul edilmekteydi ve 1994 yılında çıarılan İltica Yönetmeliğine kadar bu kapsamda yer alanlar için herhangi bir düzenleme yapılmamıştı. Özellikle İran'daki rejim değişikliği sözleşme dışı ülkelerden gelen mülteci başvurusunu oldukça arttırınca Birleşmiş Milletler Mülteciler Yüksek Komiserliği ve Türkiye arasında yapılan bir mutabakat ile Türkiye sözleşme 
harici mülteci taleplerini kendilerine başka bir ülke bulunana kadar geçici olarak kabul edecekti. Bu statüden İran dışında Afganistanlılar, Sudanlılar, Somalililer, Srilankalılar vb. ülkelerden de yararlanmak isteyen çok sayıda kişinin olması zaman içinde Türkiye'yi rahatsız etmeye başlamıştır. Bu nedenle 1994 yılında -daha sonra 1998 ve 2006' da güncellenen- İltica Yönetmeliği çıkarılmıştır (Kirişçi, 1999:118) Dış göç 2013’te yürürlüğe giren 6458 sayılı Yabancılar ve Uluslararası Kanunu’na kadar bu yönetmelik kapsamında yönetilmeye çalışılmıştır.

Türkiye’nin yoğun ve yeni bir göç türü ile karşı karşıya kaldığı bu dönemin en önemli özelliği Avrupa Birliği ile üyelik müzakerelerine başlanmış olmasıdır. Bu durum süregelen göç politikalarını da büyük ölçüde etkilemiş, göç ve iltica mevzuatının AB’nin aynı alandaki müktesebatı ile uyumlu hale getirilmesi zorunluluğu doğmuştur.

$\mathrm{Bu}$ çerçevede; Avrupa Birliği ile üye Devletlerin mevzuat yükümlülüğüne cevaben, Türk Hükümeti 2001 yılı Katılım Ortaklığg Belgesini imzalamış ve 19 Mayıs 2003 tarihinde bu belgeyi revize ederek bu doğrultuda Avrupa Birliği mevzuatının benimsenmesi için ulusal bir program takip etmeye başlamıştır. Katılım Ortaklığı Belgesinde kısa ve orta vadeli hedefler belirlenmiştir. Buna göre kısa vadede yasa dışı göç ile mücadelenin güçlendirilmesine devam edilmesi ve Avrupa Komisyonu ile bir geri kabul anlaşmasının müzakere edilmesi üzerinde durulmuştur. Orta vadede ise yasa dişı göçü önlemek amacıyla $A B$ müktesebatı ve uygulamalarının kabul edilmesi ve yürürlüğe konulması, sığınma alanında uyum sağlanması, 1951 Cenevre Sözleşmesinde getirilen coğrafi kısıtlamanın kaldırılması için çalışmalara başlanması, sı̆̆ınma başvuru ve değerlendirme sisteminin güçlendirilmesi, sığınmacılar ve mülteciler için konaklama birimlerinin oluşturulması ve sosyal destek sağlanması gibi hedefler konulmuştur. Buna ek olarak Türkiye AB’nin Adalet ve İçişleri müktesebatına uyumunu gerçekleştirmek için farklı devlet kurumlarının bir araya geldiği özel bir görev gücü oluşturmuştur. Görev gücü sınır kontrolü, göç ve iltica alanında faaliyet gösterecektir. 
Ayrıca bu alanda genel bir strateji geliştirmek amacıyla "sınırlar", "göç" ve "iltica" olmak üzere üç çalışma grubu kurmuştur. Çalışma grupları 18.06.2002 tarihinde faaliyete başlamışlardır (BMMYK ve İçişleri Bakanlığı, 2005: 6).

Özel görev gücünün kuruluşunun ardından bu alanda yapılacakları gösteren strateji belgeleri oluşturulmuştur. Bu çerçevede Türkiye'de Dış Sınırların Korunmasına İlişkin Strateji Belgesi Nisan 2003’te, Türkiye’nin Avrupa Birliğine Katılım Sürecinde İltica Alanında Yapılması Öngörülen Çalışmalara İlişkin Strateji Belgesi (İltica Strateji Belgesi) Ekim 2003’te ve Türkiye'de Göç Yönetimi Eylem Planına Katkı Sağlayacak Strateji Belgesi (Göç Strateji Belgesi) Ekim 2003’te hazırlanmıştır. (Özçürümez ve Türkay, 2011: 39).

Aynı yıl AB Topluluk Müktesebatının Benimsenmesine İlişkin 2003 yılı Türkiye Ulusal Programı ise 24 Temmuz 2003 tarih ve 25178 sayılı Resmi Gazetede yayımlanarak yürürlüğe girmiştir. Ulusal programla daha önce kısa ve orta vadeli hedefler arasında sayılan bazı hedeflerin ve işlerin uygulamaya geçirilmesiyle ilgili taahhütlerde bulunulmuştur. 2004 yılında ise AB 2002 Mali İşbirliği programlaması kapsamında Danimarka-İngiltere Konsorsiyumu ile TR02JH-03 İltica-Göç Twinning Projesini (eşleştirme projesi) uygulamaya başlamıştır. Bu projenin de genel hedefi, Türkiye’nin iltica ve göç stratejisini AB Mevzuatına uyumlaştırmak iken amacı ise $\mathrm{AB}$ fonlarından daha fazla yararlanmayı sağlayacak göç ve ilticadan sorumlu kuruluşların teknik ve idari kapasitesinin geliştirilmesini sağlamaktır (BMMYK ve İçişleri Bakanlığı, 2005: 6).

Bu çalışmaların neticesinde 2004 yılı sonunda İltica ve Göç Alanındaki Avrupa Birliği Müktesebatının Üstlenilmesine İlişkin Türkiye Ulusal Eylem Planı hazırlanmış, Plan Başbakanlıkça 25 Mart 2005’te kabul edilmiştir. 22 Haziran 2006 tarihinde İçişleri Bakanlığı Uygulama Talimatı yayınlanmıştır. Türkiye’nin iltica ve göç alanındaki iç hukukunun 1994 Yönetmeliğinden sonra ikinci temel düzenlemesi olan 57 sayılı İçişleri Bakanlığı Uygulama Talimatı sığınma usulleriyle birlikte 
mülteciler ve sığınmacıların hakları ve yükümlülükleriyle ilgili düzenlemelere yer vermiştir. Uygulama talimatına müteakiben Ulusal Program 2008'de güncellenerek Resmi Gazetede yayımlanmıştır. İltica-göç ve bütünleşik (entegre) sınır yönetimi alanında eylem planlarıyla belirlenen hedeflerle alakalı çalışmaları gerçekleştirmek ve özellikle yasal altyapı konusunda hazırlıkları koordine etmek üzere İçişleri Bakanlığında İltica-Göç ve Entegre Sınır Yönetimi adı altında 2008'de iki büro kurulmuştur. Ayrıca yasadışı göçle mücadelede alınacak tedbirlerin tespiti, kurumlar arası işbirliği ve koordinasyonun arttırılması, operasyonel faaliyetlerin en üst düzeyde izlenmesi amaciyla, büro koordinesinde Yasadışı Göçle Mücadele Koordinasyon Kurulu oluşturulmuştur (ORSAM, 2012: 21)

Müktesebat uyumlaştırılması sürecinde bu alanda AB’nin en çok sınır kontrolü ve yabancılar konusu üzerinde durduğu söylenebilir. Bu çerçevede yukarıda da yer aldığı gibi Avrupa Birliği kaçak göçü engellemek amacıyla Türkiye sınırlarının kontrol edilmesi için teknik ve maddi anlamda destek sağlamıştır. Hatta sınır kontrolünün askerlerden alınarak başka bir organizasyona verilmesi gündeme gelmiştir. Ayrıca Polis Akademisinde Sınır Güvenliği Bölümü açılmıştır. Bununla beraber yine AB etkisiyle yabancıların Türkiye'ye girişi ve bu alanda yapılan diğer faaliyetlerin daha derli toplu bir hale getirilmesi bu alandaki mevzuatın daha demokratik ve insancıl hale getirilmesi amacıyla yeni yasa çalışmalarına başlanmıştır. Bu dönem devletin göç politikaları, göç ve yabancılar hukuku sisteminde demokratikleşme olarak nitelendirilebilir (Çalı, 2012: 50).

Yukarıda da görüldüğü gibi Türkiye’nin yabancıların yoğun şekilde göç ettiği bir ülke hüviyetine bürünmesi, diğer yandan $\mathrm{AB}$ uyum sürecinin etkilerinin görülmesi ile birlikte göç alanında Türkiye'de politika üretme süreçlerinin geniş bir tartışma alanı oluşturduğu görülmektedir. Bu nedenle özellikle son 10-15 yılda ortaya çıkan pek çok yasal düzenlemeyle Türkiye'de uluslararası göç ve sığınma hareketlerine yönelik 
yeni politikaların üretilmesi ve bunların uygulamaya geçirilmesinde etkin olma gayretinin olduğu açıktır. Bu alanda yapılan başlıca hukuksal düzenlemeler ise Türkiye'de göç ile ilgili resmi bakış açısındaki değişim eğilimi ve direnmeleri açıkça göstermeleri bakımında önem arz etmekte (İçduygu, 2014: 60-61) olup, bu yasal düzenlemelerin hangileri olduğu izleyen başlıkta sıralanmıştır.

\subsection{Göç Politikasına Yön Veren Hukuki Düzenlemeler}

Türkiye'nin ana hatlarıyla yukarıda yer alan göç yönetimi politikası cumhuriyetin başından itibaren çıkarılan ulusal hukuksal metinler (yasalar, yönetmelikler, genelge, Bakanlar Kurulu Kararları, mahkeme kararları gibi) uluslararası kuruluşlar tarafından çıkarılan sözleşmeler ve AB Müktesebatına uyum kapsamında yapılan düzenlemelerle yürütülmüştür. Ayrıca ulusal programlar, kalkınma programları, ilerleme raporları, göç strateji belgesi, iltica strateji belgesi ile iltica ve göç eylem planı da bu politikanın şekillenmesinde etkili olmuştur.

Bu düzenlemelerin önemli bir kısmı içinde bulunulan dönemin konjonktürü ve dönemsel farklılıkları yansıtmaktadır. Nitekim 1951 tarihli Cenevre Sözleşmesinin imzalanması daha çok batıya ayak uydurmak ve uluslararası hukuki düzene katılabilmesi açısından önemliydi. 1994 yılında kabul edilen İltica Yönetmeliği Birleşmiş Milletler Mülteciler Yüksek Komiserliği ve uluslararası toplumla meydana gelen sorunları gidermeye dönük bir adımdır ve 2005’te kabul edilen İltica ve Göç Ulusal Eylem planı ise Avrupa Birliği ve Mülteciler Yüksek Komiserliğini tatmine dönüktür (Tolay, 2011: 210-211).

Türkiye'de son yıllarda uluslararası göç yönetimi alanında insan hakları temelinde yeni bir bakış açısının gelişmesi ve buna uygun hukuki düzenlemeler ortaya çıksa da aslında yukarıda da bir kısmına yer verildiği gibi cumhuriyetin başından itibaren alanı düzenleyen bazı düzenlemelerin olduğu görülmektedir. Ama bunların pek çoğu meseleye negatif yaklaşımları nedeniyle $\mathrm{AB}$ üyelik sürecinde yeniden ele alınması, 
güncellenmesi ve yeni politikaya uyarlanması gereken hatta bazıları bu yönde değişen yasalardır.

Bunlar arasında en önemlileri 2006 yılında değișen 1934 tarih ve 2510 sayılı İskân Kanunu, 1941 tarih ve 4104 sayılı Muharip Yabancı Ordu Mensuplarından Türkiye'ye İltica Edenler Hakkında Kanun, 1998'de değişen 1950 tarihli 5683 sayılı Yabancıların Türkiye'de İkamet ve Seyahatleri Hakkında Kanun, 1950 tarihli 5682 sayılı Pasaport Kanunu ve 1995 ile 2003’te iki kez değişikliğe uğrayan 1964 tarihli 403 sayılı Vatandaşlık Kanunudur (BMMYK ve İçişleri Bakanlığı, 2005: 7).

Ayrıca Türk Ceza Kanunu, İş Kanunu ve Yabancıların Çalışma İzinleri Hakkında Kanun, Türkiye'de Öğrenim Gören Yabancı Uyruklu Öğrencilere İlişsin Kanun'da bu yönde düzenlemeler bulunmaktadır.

Türkiye’nin göç politikasına yön veren yukarıdaki yasaların yanı sıra bu süreçte yönetmelik, genelge, yönerge, tebliğ ve Bakanlar Kurulu kararları gibi ikincil düzenlemeler de yapılmıştır. Bunlardan birkaçı aşağıda sıralanmıştır (Göç İdaresi, 2015):

- Türkiye’ye İltica Eden veya Başka Bir Ülkeye İltica Etmek Üzere Türkiye'den İkamet İzni Talep Eden Münferit Yabancilar ile Topluca Sığınma Amacıyla Sınırlarımıza Gelen Yabancılara ve Olabilecek Nüfus Hareketlerine Uygulanacak Usul ve Esaslar Hakkında Yönetmelik,

- Mülteci Misafirhaneleri Yönetmeliği,

- Doğrudan Yabancı Yatırımlarda Yabancı Uyruklu Personel İstihdamı Hakkında Yönetmelik,

- Türkiye'de Oturan Yabancıların Nüfus Kayıtlarının Tutulması Hakkında Yönetmelik,

- Türkiye’de Öğrenim Gören Yabancı Uyruklu Öğrencilere İlişkin Yönetmelik,

- Doğrudan Yabancı Yatırımlar Kanunu Uygulama Yönetmeliği, 
- Yabancıların Çalışma İzinleri Hakkında Kanunun Uygulama Yönetmeliği,

- Kabul, Barınma ve Geri Gönderme Merkezleri ile İlgili Yönetmelik,

- Geçici Koruma Yönetmeliği,

- 25/09/1968 tarihli ve 6/10733 sayılı Bakanlar Kurulu Kararı ile yürürlüğe konulan Mültecilerin Hukuki Statüsüne İlişkin 31 Ocak 1967 tarihli Protokolü,

- Geri Kabul Antlaşmasıyla İlgili Başbakanlık Genelgesi,

- "Sınır Kapılarında Verilen Vizelerle İlgili Bakanlar Kurulu Kararı"dir.

Bu konuda yapılan son düzenleme 2013’te çıkarılan ve bu alanı bütüncül bir biçimde insan hakları temelinde düzenleyen, "Göç İdaresi", "Göç Politikaları Kurulu” gibi idari yapıların oluşumuna zemin hazırlayan 6458 sayılı Yabancılar ve Uluslararası Koruma Kanunu'dur. Kanun etkin bir iltica sistemi kurmak ve yönetmek, mülteci haklarını uluslararası standartlara uydurmak amacıyla önemli konulara yer vermiştir.

Toplam 126 maddelik kanun 5 kısım ve alt bölümlerden oluşmaktadır. Birinci kısımda yasanın amacı, kapsamı hakkında bilgi verilmiştir.

İkinci kısım Türkiye'ye giriş ve çıkış yapan yabancıları, onların ikamet izinleri ile sınır dışı edilmelerini konu almaktadır.

Üçüncü kısımda ise uluslararası koruma başlığı altında mülteci, şartlı mülteci, ikincil koruma, bu kişilerin başvurusu, değerlendirilmesi, mülteci veya geçici sığınma statüsü verilmesi vb. konular yer almaktadır.

Dördüncü kısım yabancılar ve uluslararası ortak hükümlere yer verirken beşinci ve son kısımda ise göç idaresi, göç politikaları kurulu gibi yapıların kuruluş ve görevleri ile merkez, taşra ve yurt dışı teşkilatları hakkında bilgi vermektedir. 


\subsection{Göç Politikasının Belirlenmesi ve Yürütülmesinde Kurumsal} Yapi

Yakın zamana kadar Türkiye'de salt sınır dışı göçü yönetmek, politika belirlemek ve uygulamakla görevli kurumsal yapı veya yapılanmaların olduğu söylenemez. Bu alanın yönetimi farklı yönleri ile görev almış bazı kuruluşlar arasında dağılmıştı. Bu süreçte İçişleri Bakanlığına bağlı Emniyet Genel Müdürlüğünün Yabancılar Şubesi ve Valilikler özellikle ülkeye giriş yapmış yasa dışı göçmenleri kontrol altına alma onları, toplama merkezlerine yerleştirme ve gerektiğinde sınır dışı etme konularıyla ilgilenmekteydiler. Özellikle AB üyelik sürecinde ilgili müktesebatın uyarlanması ve yoğun düzensiz göçlerin etkisiyle hem kurumsal yapilar hem de rollerinin belirgin hale gelmesi, idari kapasitelerinin geliştirilmesi yönünde çalışmalar ve talepler gündemden eksik olmamıştır. Gelinen nokta itibariyle göç politikasının tespiti ve uygulamasının nasıl olacağ 2013 yılında çıkarılan Yabancılar ve Uluslararası Koruma Kanunu ile belirlenmiştir. Kanundaki amir hükümlerin ve genel olarak Türkiye'deki kamu politikalarının tespiti de göz önünde bulundurularak bu alanda faaliyet üstlenen kuruluşlar merkezi ve yerel düzeyde olmak üzere iki şekilde ele alınabilir.

\subsubsection{Merkezi Düzeyde Göç Yönetimi}

Türkiye'de hem 6458 sayılı Yabancılar ve Uluslararası Koruma Kanununun öngördüğü göç yönetimi yapılanması hem de öncesinde oluşturulmuş parçalı göç yönetimi yapılanması bütünüyle merkezi yönetimi ve taşra uzantılarının ağırlıkta olduğu bir görünüm arz etmektedir. $\mathrm{Bu}$ nedenle göç yönetimi ile ilgili kurumsal yapılar genellikle başkentte örgütlenmiş ve taşra teşkilatları aracılığıyla belirledikleri politikaları ve aldıkları kararları uygulamaya geçirmektedirler.

Bakanlar Kurulu: Merkezi düzeyde göç politikasının en üst ve ana belirleyicisinin Bakanlar Kurulu olduğunu söylemek mümkündür. Kolektif bir sorumlulukla genel olarak hükümet politikasının anayasa, 
kanunlar, hükümet programı ve kalkınma planları gibi temel düzenleyici metinler bağlamında belirlenmesi, uygulanmasının takibi ve denetiminden sorumludur. Bu kapsamda Bakanlar Kurulu diğer hükümet politikaları gibi göç politikasını da genel hatları ile belirler, uygulanmasinı takip eder ve denetler.

Göç Politikaları Kurulu: Yukarıda da görüldüğü gibi Bakanlar Kurulu Türkiye'deki kamu politikalarının tespiti, uygulanmasının takibi ve denetlenmesinde ana aktör olmakla birlikte her zaman bütün bakanların toplanması ile iş görmez. Geçmişten beri Bakanlar Kurulunun görev alanına giren bazı çalışmaları belli bakan veya bakanlıkların görevlendirildiği daha az üyeli kurul ve komisyonlar eliyle de yerine getirilmektedir (Güler, 2013: 156). Daha az bakanın veya bakanların görevlendirdiği kişilerin katılımıyla oluşturulan bu kurullardan biri de göç yönetimi alanında görev yapmak üzere 6458 sayılı Yabancılar ve Uluslararası Koruma Kanunu’nun 105. maddesi ile düzenlenen Göç Politikaları Kuruludur. Kurul, İçişleri Bakanının başkanlığında, Aile ve Sosyal Politikalar, Avrupa Birliği, Dışişleri, Çalışma ve Sosyal Güvenlik, Kültür ve Turizm, Maliye, Milli Eğitim, Sağlık, Ulaştırma Denizcilik ve Haberleşme bakanlıkları müsteşarları ile Yurt Dışı Türkler ve Akraba Topluluklar Başkanlığı Başkanı ile Göç İdaresi Genel Müdüründen oluşmaktadır. Kurul, başkanın çağrısı üzerine yılda bir kez toplanır, gerektiğinde başkanın çağrısıyla olağanüstü toplantılar da yapabilir. Toplantı gündemi üyelerin görüşü de alınarak başkan tarafından belirlenir. Kurulun sekreterya hizmetleri ise Göç İdaresi Genel Müdürlüğünce yürütülür.

Kurulun başlıca görevleri; Türkiye'nin göç politika ve stratejilerini belirlemek, uygulamasını takip etmek, bu alanda program belgeleri ve uygulama belgelerini hazırlamak, kitlesel akımlar olması halinde uygulanacak yol ve yöntemleri belirlemek, insani amaçlarla Türkiye'ye toplu halde kabul edilen yabancıların ülkeye giriş ve ülkede kalış usullerini belirlemektir. Ayrıca yabancılara verilecek uzun dönemli ikamet izinlerine ilişkin şartları tespit etmek, göç alanında görev yapan kamu kurum 
ve kuruluşları arasında koordinasyonu sağlamak ve göç alanında faaliyet yürüten uluslararası kuruluşlarla işbirliği yapmak da kurulun görevleri arasındadir.

Göç İdaresi Genel Müdürlüğü: Merkezi düzeyde göç yönetimi alanında faaliyet yürüten diğer bir yapı yine aynı kanunun 103. maddesiyle İçişleri Bakanlığına bağlı olarak kurulmuş olan Göç İdaresi Genel Müdürlüğüdür. Müdürlük bu alanda kamu politikasının yürütülmesi, işbirliklerin sağlanması, iş ve işlemlerin yapılmasından sorumlu olup bu amaçla 81 İl, 148 İlçe ve yurtdışında teşkilatlanmıştır. Genel Müdürlük taşradaki yapılanmasını tamamlayarak 18 Mayıs 2015 tarihi itibariyle bütün illerde görevleri Emniyet Genel Müdürlüğünden devralmıştır (Göç İdaresi, 2015).

Genel Müdürlüğün ana hizmet birimleri adı geçen kanunun 108. maddesinde sayılmıştır. Buna göre Genel Müdürlük göç ile ilgili hizmetleri Yabancılar Dairesi Başkanlığı, Uluslararası Koruma Dairesi Başkanlığı, İnsan Ticareti Mağdurlarının Koruması Daire Başkanlığı, Göç Politika ve Projeleri Daire Başkanlığı, Uyum ve İletişim Başkanlığı gibi daire başkanlıkları eliyle yürütmektedir.

Genel Müdürlüğün başlıca görev ve yetkileri ilgili kanunun 104 . maddesinde aşağıdaki gibi sayılmıştır:

- Göç alanındaki, mevzuatın ve idari kapasitenin geliştirilmesi, politika ve stratejilerin belirlenmesi konularında çalışmalar yaparak Bakanlar Kurulunca belirlenen politika ve stratejilerin uygulanmasını izlemek ve koordine etmek,

- Göç Politikaları Kurulunun sekretarya hizmetlerini yürütüp, Kurul kararlarının uygulanmasını takip etmek,

- Göç, insan ticareti mağdurlarının korunması ve geçici korumaya yönelik iş ve işlemleri yerine getirmek,

- 19.9.2006 tarihli ve 5543 sayılı İskân Kanununda Bakanlığa verilen görevleri yürütmek, 
- Düzensiz göçle mücadelenin yapılabilmesi maksadıyla kolluk birimleri ve ilgili kamu kurum ve kuruluşları arasında koordinasyonu sağlamak, tedbirler geliştirip bunları uygulamak ve takip etmek,

- Göç alanında faaliyet sürdüren kamu kuruluşlarının çalışmalarının programlanmasına ve projelendirilmesine yardımcı olmak, proje tekliflerini değerlendirmek, bunları onaylamak, yürütülen çalışma ve projeleri izlemek ve bu çalışma ve projelerin uluslararası standartlara uygun şekilde yürütülmesine destek vermek ve

- Türkiye'de bulunan vatansız kişileri tespit edip, bunlarla ilgili iş ve işlemleri yapmaktır.

\subsubsection{Göç Yönetiminde Görevli Diğer Yapılar}

Merkezi düzeyde göç yönetiminde genel müdürlüğe bağlı ve belli aralıkla çalışacak şekilde bazı kurul ve komisyonların da önemli görevler üstlendikleri görülmektedir. Bu kurul ve komisyonlar ilgili kanunun 113 ve 117. maddeleri arasında düzenlenmiş olup temsil düzeyi değişmekle birlikte kamu kurumları temsilcileri, öğretim elemanları ve gerektiğinde bu alanda faaliyet yürüten küresel kuruluşların temsilcilerinden oluşmaktadır. Yönetişim benzeri bir anlayışla çalışan kurul ve komisyonlar "Göç Danışma Kurulu”, "Uluslararası Koruma Değerlendirme Komisyonu” ve “Düzensiz Göçle Mücadele Koordinasyon Komisyonu" dur.

Göç Danışma Kurulu: Kurul Bakanlık müsteşarı veya görevlendireceği müsteşar yardımcısının başkanlığında olmak üzere Türkiye İnsan Hakları Kurumu, Avrupa Birliği, Çalışma ve Sosyal Güvenlik ve Dışişleri bakanlıklarının en az daire başkanı seviyesindeki temsilcileri, Genel Müdür, genel müdür yardımcıları, Yabancılar Dairesi, Uluslararası Koruma Dairesi, İnsan Ticareti Mağdurlarını Koruma Dairesi, Uyum ve İletişim Dairesi ve Göç Politika ve Projeleri Dairesi başkanları, Birleşmiş Milletler Mülteciler Yüksek Komiserliği Türkiye Temsilcisi, Uluslararası 
Göç Örgütü Türkiye Temsilcisi ile göç konularıyla ilgili beş öğretim elemanı ve göç alanında çalışmalarda bulunan beş sivil toplum kuruluşu temsilcisinden oluşmaktadır.

Kurulun başlıca görevleri göç alanında yapılan politikaları izleme, bunlarla ilgili önerilerde bulunma, bu konuda yapılacak yeni politikalarla ilgili olarak değerlendirmede bulunmaktır. Kurul ayrıca göç alanında uluslararası ve bölgesel politikaları analiz ederek bunların Türkiye’ye yansımalarını incelemek, göç ile ilgili mevzuat çalışmaları ve uygulamalarını değerlendirmek gibi görevlere de sahiptir.

Uluslararası Koruma Değerlendirme Komisyonu: Komisyon Göç İdaresi Genel Müdürlüğün belirleyeceği temsilcinin başkanlığında, Adalet ve Dışişleri bakanlıklarınca görevlendirilen birer temsilci ve bir göç uzmanından oluşmaktadır. Komisyona, Birleşmiş Milletler Mülteciler Yüksek Komiserliği Türkiye Temsilciliği yetkilisi de gözlemci olarak katılmak üzere davet edilebilir. Bu amaçla Göç İdaresi Genel Müdürlüğünde ve taşra teşkilatında birden fazla komisyon kurulabilir. Genel müdürlük ve göç uzmanı en az iki yıl diğerleri ise bir yıl için asıl ve yedek üye olmak üzere belirlenir.

Komisyonun iki temel görevi bulunmaktadır: Birincisi göç yönetiminin yetkili birimlerine yapılmış uluslararası sığınma başvuruları üzerine verilen kararlarla (idari gözetim, kabul edilemez başvuru ve hızlandırılmış değerlendirme sonucu verilmiş kararlar hariç) ilgili itirazları değerlendirmek ve karara bağlamaktır. Diğeri ise uluslararası korumanın iptali ya da sona ermesine ilişkin olarak yapılan itirazları değerlendirmek ve bu amaçla karar vermektir.

Düzensiz Göçle Mücadele Koordinasyon Kurulu: Kurul İçişleri Bakanlığı Müsteşarı veya görevlendireceği müsteşar yardımcısı başkanlığında, Genelkurmay Başkanlığı, Çalışma ve Sosyal Güvenlik ve Dışişleri bakanlıkları ile Millî İstihbarat Teşkilatı Müsteşarlığı, ilgili kolluk birimleri ve Göç İdaresi Genel Müdürlüğünün en az daire başkanı seviyesindeki temsilcilerinin katılımıyla oluşmaktadır. Gerektiğinde kurul 
toplantılarına ilgili kamu kurum ve kuruluşlarının merkez ve taşra birimleri, sivil toplum kuruluşları, uluslararası kuruluş temsilcileri ve konuyla ilgili uzmanlar da çağrılabilir. Kurul, gündemli olarak altı ayda bir toplanmakla birlikte gerektiğinde başkanın çağrısıyla her zaman olağanüstü toplanabilir.

Kurulun görevleri düzensiz göç ile etkin mücadele edebilmek amacıyla ilgili kamu kurum ve kuruluşları arasında koordinasyonu sağlamak, yasa dışı biçimde Türkiye'ye yapılan giriş ve çıkış yollarını tespit ederek bununla ilgili önlemler geliştirmek, düzensiz göçle alakalı tedbirleri almak, bu alanda geliştirilip, uygulanacak mevzuat ile ilgili çalışmaları planlamak ve uygulamasını izlemektir.

Afet ve Acil Durum Yönetimi Başkanlığı (AFAD): Sınır dışı göç yönetiminde merkezi düzeyde görevli kurum, kurul ve komisyonlarla ilgili bu başlığı kapatmadan önce yine merkezde örgütlenmiş ancak taşra birimleriyle de bu alanda belli roller üstlenmiş olan Başbakanlık Afet ve Acil Durum Yönetimi Başkanlığı (AFAD) hakkında da biraz bilgi vermekte fayda bulunmaktadır. Başkanlık öncelikli olarak deprem, sel vb. doğal afetlere daha etkin müdahale edilmesi ve daha sonrasında iyileştirme faaliyetlerinin hızla tamamlanması amaciyla kurumlar arasında gerekli planlamayı yapmak, koordinasyonu sağlamak vb. işleri yürütmek üzere kurulmuştur. Ancak kuruluş amacı bu şekilde belirlenmiş olsa da özellikle son 4 yıldır Suriye'de yaşanan çatışmalı ortamdan kaçarak Türkiye'ye gelen sı̆̆ınmacıların barınması için merkezler kurulması ve bu merkezlerde bazı hizmetlerin sunulması görevi de AFAD tarafından yüklenilmiştir. Bu kapsamda süreç içerisinde Türkiye'ye giriş yapan yaklaşık 2 milyon Suriyeli'den 250 bini AFAD'ın on ilde kurduğu ve yönettiği 25 barınma merkezinde yaşamını sürdürmektedir. İlgili bakanlık, kamu kurum ve kuruluşları ile Türk Kızılay’ı işbirliği ile çadır kentlerde ve konteynır kentlerdeki barınma, iaşe, sağlık, güvenlik, sosyal etkinlikler, eğitim, ibadet, tercümanlık, haberleşme, bankacllık ve benzeri diğer hizmetler verilmektedir. Bu zamana kadar verilen 
bu hizmetlerin parasal karşılığı ise yaklaşık 5.6 milyar ABD dolarıdır (AFAD, 2015).

\subsubsection{Yerel Düzeyde Göç Yönetimi}

Yerel düzeyde göç yönetiminden maksat il düzeyinde bu alanda hangi kurumların sorumlu olduğunu ortaya koymaktır. Bu çerçevede bakıldığında yerel düzeyde göç yönetiminde sorumluluğun büyük ölçüde bu amaçla merkezde kurulmuş kamu kuruluşlarının taşra birimlerinde olduğu görülmektedir. Burada valiler genel sorumlu olmakla birlikte bu görevi Göç İdaresi ve Afet Acil Durum İl Müdürlükleri üzerinden yürütmektedirler. Her iki müdürlüğün görevleri bir birinden farklı olmakla birlikte aralarında belli ölçülerde koordinasyon ve işbirliği bulunmaktadır.

Yerel düzeyde Göç İdaresi İl Müdürlüklerinin sınır dışı kitlesel göç karşısındaki görevi bu kişilerin kayıt altına alınması, istatistiklerinin tutulması, oturma izinleri, sınır dışı edilmeleri vb. iken Afet ve Acil Durum Müdürlükleri ise il düzeyinde çadır kent ve konteynır kentlerin yönetiminden sorumludurlar. Bu çerçevede barınma, gıda, giyim, sağlık, eğitim gibi hizmetler koordine edilmektedir.

Yerel düzeyde göç yönetiminden doğrudan sorumlu olan merkezi yönetim birimlerinin rol ve görevlerini kısaca gördükten sonra yerel yönetimlerin (belediye, il özel idaresi ve köyler) bu yönetimdeki yeri ve görevlerinin de irdelenmesi gerekmektedir. Çünkü vatandaşa en yakın, onların sorunlarına daha vakıf olan ve karar organları halk tarafından belirlenen, belli özerklikler temelinde faaliyet yürüten birimler olarak yerel yönetimlerin bu yönetimdeki rolü de büyük önem arz etmektedir. Ayrıca gelişmiş ülkelerdeki kamusal hizmetlerin büyük bölümünün yerel yönetimlerce yapılıyor olması da bu önemi arttırmaktadır.

Türkiye'de sınır dışı göç genel itibariyle merkezi yönetime ait bir sorun olarak algılanıp, ilk bakışta yerel yönetimleri ilgilendirmiyor gibi 
görünse de aslında göç eden kişilerin belli sürelerde Türkiye'de yaşamaları onların yerel yönetimlerin görev yürüttükleri alanlarda ikamet ettikleri gerçeğini ortaya çıkarmaktadır. Özellikle belediyelerin örgütlendikleri kentsel alanlarda göç ve göçmenlerin etkisi daha fazla görülmektedir.

Öyle ki sadece son 4 yılda Suriye ve Irak'tan Türkiye'ye yönelen kitlesel sınır dışı göç miktarı yaklaşık 2 milyon kişi civarındadır. Bunların ancak 250 bin kişilik kısmı bugün merkezi yönetime bağlı barınma merkezlerinde yaşamlarını sürdürmektedir. Bu durumda 1.5 milyondan fazla kişinin Türkiye'nin çeşitli kentlerine dağıldığg 1 ve yerel yönetim hizmetlerinden istifade ettikleri anlaşılmaktadır. Böylece belli nüfuslar esas alınarak oluşturulan yerel yönetim birimleri özellikle de belediye idareleri üzerinde pek çok açıdan olumsuz etki oluşturmaktadır.

Günümüzde büyükşehir statüsünü kazanmış illerde belediye dişındaki yerel yönetimler olan il özel idareleri ve köyler yasal olarak kald1rıldığından bu yerleşim yerlerinde sorumluluk tümüyle belediye idarelerine geçmiş durumdadır. Nitekim belediyelerin görevli olduğu kentsel bölgelerde ulaşım, kent içi düzen, barınma, çevre-temizlik, zabıta hizmetleri (özellikle dilencilikle mücadele), su sağlama vb. kamusal hizmetler kitlesel göçten en fazla etkilenen alanlar olarak görülmektedir.

Özellikle belediyeler büyük ölçüde nüfus ölçütü esas alınarak merkezi yönetim bütçesinden almış oldukları payı göçten kaynaklı fazla nüfus için de harcamak durumunda kalmaktadırlar. Gerçekte hangi şehirde kaç göçmenin yaşadığının tam olarak bilinmemesi bazı belediyeleri daha fazla maddi külfetle karşı karşıya bırakmaktadır. Öyle ki Orta Doğu Stratejik Araştırmalar Merkezi (ORSAM) 'nin TESEV işbirliği ile 2015 yılında hazırlamış olduğu Suriyeli Sığınmacıların Türkiye’ye Etkileri adlı raporda kentlerdeki yoğunluklarına göre göçle gelenlerin belediye bütçeleri üzerinde ek yüzde onluk maliyete sebep oldukları belirtilmektedir (ORSAM ve TESEV, 2015: 36). 
Bütün bu realiteye karşın başta belediyeler olmak üzere yerel yönetimlerin ulusal göç yönetimindeki yeri tam olarak belli değildir. $\mathrm{Bu}$ alanı düzenleyen temel kanun niteliğindeki 6458 sayılı Yabancılar ve Uluslararası Koruma Kanunu'nda yerel yönetimlerin bu çalışmaların neresinde yer aldığı, bu alandaki politikanın belirlenmesi ve uygulanmasındaki rolleri hakkında herhangi bir düzenlemeye yer verilmemiştir. Sadece ilgili kanunun Göç İdaresinin görev ve yetkileri başlıklı 104. maddesinin ikinci fikrasında; "Genel Müdürlük, görevleriyle ilgili konularda kamu kurum ve kuruluşları, üniversiteler, yerel yönetimler, sivil toplum kuruluşları, özel sektör ve uluslararası kuruluşlarla iş birliği ve koordinasyonu sağlamakla yetkilidir." denilerek bu birimlere kısmi bir paydaşlık statüsü verildiği söylenebilir.

Uygulamada genelde yerel yönetimler özelde ise belediyelerin daha çok kendi kanunlarından belli ölçülerde yetki alarak göçmenlere yönelik sosyal amaçlı yardımlar yaptıkları anlaşılmaktadır. Nitekim 5393 sayılı kanuna tabi belde, ilçe ve büyükşehir dışındaki belediyelerin bu amaçla yaptıkları veya yapacakları yardımlar ilgili kanunun 14. maddesindeki "belediyeler ... acil yardım, kurtarma, ... sosyal hizmet ve yardım... belli bir nüfusun üzerindeki belediyeler kadın ve çocuklar için konuk evleri yapabilir... gıda bankacılığı kurabilir” ibaresine dayandırılmaktadır.

5393 sayılı Belediye Kanununda göç yönetimi konusunda doğrudan belediyelere verilmiş bir yetki ve görevden bahsedilemeyeceği gibi Büyükşehir Belediyelerini düzenleyen 5216 sayılı kanunun belediye yetkileri başlıklı 7. maddesinde de da böyle bir düzenleme görülmemektedir. Ancak ilgili kanunun 7. maddesinin "u" fikrası (il düzeyinde yapılan plânlara uygun olarak, doğal afetlerle ilgili plânlamaları ve diğer hazırlıkları büyükşehir ölçeğinde yapmak; gerektiğinde diğer afet bölgelerine araç, gereç ve malzeme desteği vermek; itfaiye ve acil yardım hizmetlerini yürütmek) ile "v" fikralarında (sağlık merkezleri, hastaneler, gezici sağlık üniteleri ile yetişkinler, yaşlılar, engelliler, kadınlar, gençler ve çocuklara yönelik her türlü sosyal ve kültürel hizmetleri yürütmek, geliştirmek 
ve bu amaçla sosyal tesisler kurmak...) sayılan görevler bu kapsamda değerlendirilebilir.

Yine Büyükşehir ilçe belediyelerinin; yaşlılar, engelliler, kadınlar, gençler ve çocuklara yönelik sosyal ve kültürel hizmetler sunmak, şeklindeki görevlerini de bu derlendirmek mümkündür.

Aynı şekilde İl Özel İdarelerini düzenleyen 5302 sayılı kanunda da göç ve göç yönetimi konusunda bu idarelere verilmiş açı bir yetki ve göreve rastlanmamaktadır. Kanunun 6. maddesinde İl Özel İdarelerinin... sosyal hizmet ve yardımlar, yoksullara mikro kredi verilmesi, çocuk yuvaları ve yetiştirme yurtları... gibi görevleri yapabilecekleri belirtilmektedir. Bu da İl Özel İdarelerinin bu alanda çalışmalarına imkân tanımaktadır.

Burada bir diğer yerel yönetim birimi olan köylerin bu alandaki çalışmalarından bahsetmenin anlamsız olduğunu belirtmek gerekir. Zira köyler var olan kaynakları ile kendilerine bile yetecek durumda değillerdir.

Yasalarda bu alandaki yetkileri yeterince açık olmamakla birlikte, özellikle belediyelerin sınır dışı göç konusunda önemli çalışmalar yürüttükleri ve harcama yaptıkları görülmektedir. Öyle ki genel bir araştırma yapıldığında Türkiye'deki belediyeler özellikle Suriyeli sığınmacılara yönelik gıda, giyim vb. acil ihtiyaçların bir kısmını sağlama, kitlesel halde Türkiye’ye sığınmış bu kişilere yönelik yardım kampanyaları başlatma şeklinde faaliyetler yürütmektedirler. Mesela İstanbul Büyükşehir Belediyesinin Kasım 2014’te başlattığg “Suriyeli Kardeşlerimiz İçin El Ele” kampanyası ile dört tır yardım toplanmış ve Gaziantep ile K. Maraş’a gönderilmiştir. Yine Ankara Büyükşehir Belediyesi’nin "Bu Çaresizliğe Dur De” kampanyası ile içinde gıda, giyim, temizlik, eğitim malzemesinin yer aldığı 39 tır yardım toplanmış ve Kahramanmaraş’taki kamplara gönderilmiştir. Aynı şekilde Suriye sınırında yer alan Şanlıurfa, Gaziantep, Mardin, Hatay gibi büyükşehir belediyeleri ile Diyarbakır Büyükşehir belediyesi bu anlamda daha fazla hizmet sunarak büyük maddi külfetler altına girmişlerdir. 
Türkiye'de özellikle sınırdaki yerel yönetim birimlerinin/belediyelerin Suriye, Irak kaynaklı akut kitlesel göç hareketleri karşısında görev ve rolleri yukarıdaki gibi görünmekle birlikte bu sorunun kalıcı hale gelmesi ve bu kişilerin Türkiye'de devamlı ikamet etmeleri halinde uyum sorunlarının ortaya çıkacağı açıktır. Bu da Avrupa'da olduğu gibi yerel yönetim birimlerine uzun vadede daha fazla külfet yükleyecek ve onların bu konuda daha fazla politika, hizmet üretmesi ya da ulusal politikanın bir parçası haline gelmesini zorunlu hale getirecektir.

Güney sınırımızdan kaynaklı bu özel durum bir yana şimdiye kadar kalıcı hale gelen veya gelme ihtimali olan göçmenlerin kente uyumları konusunda yerel yönetimlerin kayda değer bir çalışma yürüttükleri söylenemez. Sadece geçtiğimiz yıllarda İstanbul'da Zeytinburnu belediyesinin bu konuya dikkat çekmek amacıyla Uluslararası Göç, Entegrasyon gibi konularda uluslararası bilimsel çalışmalar yaptığı da görülmektedir. Oysa Türkiye’nin üye olmaya çalıştığ $\mathrm{AB}$ ülkelerinin çoğunda yerel yönetimlerin özellikle göçmenlerin ülke ve kente uyumu (entegrasyonu) konusunda önemli görevler üstlendikleri bilinmektedir. AB ülkelerinde göçmen başvuruları genellikle ulusal düzeyde incelenmekte ama onların yerleşimleri ve iş bulmaları ise yerel düzeyde gerçekleşmektedir. $\mathrm{Bu}$ nedenle Avrupa Birliği üye ülkelerinin önemli şehirlerinin yerel yönetimleri de özellikle göçmenlerin kente ve topluma uyumu, daha iyi yaşamaları, yerel hizmetlere ve kentsel idarelerin karar alma mekanizmalarına katılımları ve yerel hizmetleri daha nitelikli bir şekilde alabilmeleri için bazı adımlar attıkları görülmektedir. Amsterdam "Kültürel Çeşitlilik Bürosu”, Birmingham kentinde kurulan "Toplum İlişkileri Kurulu, Sürekli Danışma Formu ve Eşitlik Bölümü”, Bolonya "Bolonya ve Yetki Alanındaki Üçüncü Ülkelerin Vatandaşları Metropol Formu”, Frankfurt "Çok Kültürlülük İşleri Bürosu”, Madrid "Belediye Kültürler Arası Arabuluculuk Birimi”, Viyana "Entegrasyon Evi” bu amaçla kurulmuş birimlerdir (Murat ve Taşkesenlioğlu, 2009: 127-151). 


\section{Sonuç ve Öneriler}

Tarihin hemen her döneminde karşılaşılan göç hareketleri son yüzyılda yoğunlaşmış ve hem göç veren hem de göç alan ülkeler bakımından bazı sorunlar oluşturmaya başlamıştır. Buna karşın gerek devlet gerekse küresel örgütlerin göç yönetimi politikaları görece daha geç başlamıştır. Günümüzde hala yoğun şekilde yaşanan ve önemli bir kısmı ölümle sonuçlanan ve daha çok düzensiz yani yasa dışı göçler bazı ülkelerin bu alanda katı tutumlar sergilemesine yol açmaktadır. Fakat diğer taraftan günümüzde özellikle savaş, çatışma vb. nedenlerle başka ülkelere sığ1nan insanların hakları da hem ulusal hem de küresel düzeyde bazı hukuksal metinlerle güvence altına alınmıştır.

Tarihsel bir olgu olan göçten Türkiye de uzun süredir doğrudan veya dolaylı olarak etkilenmektedir. Cumhuriyetin başında ulus devlet inşası ve kurumsallaşmasına hizmet etmesi amacıyla bilinçli bir şekilde yararlanılan göç hareketleri son 30 yılda yeni bir şekil almıştır. $\mathrm{Bu}$ dönemde Türkiye özellikle Avrupa ülkelerine geçmek isteyen düzensiz göç yollarından biri olarak Asya ve Afrika kaynaklı göç hareketlerine maruz kalmış, diğer yandan son 4-5 yıldır güney sınırındaki Suriye ve Irak'ta meydana gelen iç savaş nedeniyle yoğun bir şekilde sığınmac1larla yüz yüze kalınmıştır. Bundan dolayı yaklaşık 2 milyon insan Türkiye'nin çeşitli kentlerine dağılarak merkezi yönetim ve yerel yönetim hizmetleri üzerinde ek yük oluşturmaktadır.

Türkiye tarih içinde karşılaştığı bu göç hareketleri karşısında belli bazı politikaları merkezi yönetim eliyle uygulamaya koymuş ve bu alanda yukarıda isimleri zikredilen yasal düzenlemeleri ortaya koyarak kurumsal yapıları ve kurulları oluşturmuştur. Özellikle AB ile üyelik müzakerelerine başlanmasıyla Türkiye'nin iltica ve göç mevzuatı da $\mathrm{AB}$ müktesebatına uyguna hale getirilmeye çalışılmaktadır. Bu amaçla hem ulusal eylem planları hazırlanmış, hem strateji belgeleri ilan edilmiş hem de insan hakları temelinde bütüncül bir bakış açısıyla bu alanı düzenlemek üzere yakın zamanda Yabancılar ve Uluslararası Koruma 
Kanunu çıkarılmıştır. Kanunla göçün yönetimi için kurumsal yapılar da teşekkül etmiştir. Ancak göçten genel itibariyle etkilenenler en çok kentler ve kent yönetimleri (belediyeler) olmasına karşın yasal olarak ve kurumsal düzeyde göç yönetimi konusundaki rollerinin açık olmadığı veya sınırlı kaldığı görülmektedir.

Bir yerel yönetim birimi olarak belediyelerin özellikle son kitlesel sınır ötesi göç konusunda üstlendikleri görev sosyal-yardım ve sosyal hizmet eksenli olup, yasal dayanağı belediye kanunlarındaki görev ve yetkiler olmuştur. Son dönemde sadece Suriye'den gelen göçün yaklaşık bir buçuk milyonunun kentlere dağıldığ dikkate alındığında bu kişilerin belediyelerin sağlamış olduğu su, kanalizasyon, altyapı, çevre-temizlik gibi pek çok hizmetinden istifade ettikleri açıtır. Bu durum aynı zamanda büyük ölçüde nüfus, gelişmişlik ve yüzölçümü esasına göre oluşan belediye bütçelerine ciddi bir külfet oluşturmaktadır.

$\mathrm{Bu}$ durumda kentteki göçün kente uyumu, kentsel hizmetlerden daha iyi yararlanması için başta belediyeler olmak üzere yerel yönetimlerin göç yönetimi süreçlerine aktif bir aktör olarak katılmasının önünü açacak yasal düzenlemeler yapılmalıdır. Buna ek olarak gerek ulusal-gerekse yerel düzeyde göç politikasının belirlenmesi için oluşturulan kurullarda belediye ve diğer yerel yönetim temsilcilerine de yer verilmesi gerekmektedir. Ayrıca belediyelere göçmenlerin kente kabulü, yerleşme ve ikametleri gibi alanlarda belli yetkiler tanınabilir. Yoğun göç alan illerde göçmen nüfusun Belediye bütçelerinde meydana getirdiği ek yükü hafifletmek için söz konusu belediyelerin genel bütçeden alacakları pay arttırılmalıdır. Belediyelerin bu alanda hizmet verecek personel kapasitesi güçlendirilmelidir. 


\section{Kaynakça}

Aktar, Ayhan (2012), Varlık Vergisi ve Türkleştirme Politikaları, İstanbul: İletişim Yayınları.

Anich, Rudolf, Brian, Tara and Laczko, Frank (2013), World Migration Report 2013, (Ed. Frank Laczko and Gervais Appave), Switzerland: International Organization for Migration.

Barkın, Ersan (2014), "1951 Tarihli Mülteciliğin Önlenmesi Sözleşmesi”, Ankara Barosu Dergisi, Yıl 72, Sayı 2014/1, ss. 333-360.

Birleşmiş Milletler Mülteciler Yüksek Komiserliği ve İçişleri Bakanlığ1 (2005), İltica ve Göç Mevzuatı, Ankara: BM Mülteciler Yüksek Komiserliği ve İçişleri Bakanlığı Yayını.

Çalı, Hasan Hüseyin (2012), "Kamu Politikası Olarak Türkiye’nin Göç Politikası", İdarecinin Sesi Dergisi, Haziran-Mayıs 2012, ss. 47-50.

Çelebi, Özlen (2011), "Kuramların Sessizliği: Liberalizm, Realizm ve İltica Rejiminin Kuruluşu", İltica, Uluslararası Göç ve Vatansızlık: Kuram, Gözlem ve Politika, (Ed. Ö. Çelebi, S. Özçürümez ve Ş. Türkay), Ankara: Birleşmiş Milletler Mülteciler Yüksek Komiserliği Yayını, ss.9-26.

Gautam, Tika Ram (2005), "Causes and Impact of Migration : A Sociological Study of Emigration From Kandebash, Baglung, Nepal”, Dhaulagiri Journal of Sociology and Anthropology, Volume 1, pp.146-163.

Göç İdaresi Genel Müdürlüğü (2015), Göç, Göç Tarihi, Göç İdaresi, Göç İle İlgili Uluslararası Kuruluşlar, http://www.goc.gov.tr/icerik3/uluslararasi-kuruluslar_363_392_394, (Erişim Tarihi: 20.05.2015).

Güler, Birgül Ayman (2013), Türkiye’nin Yönetimi Yapı, Ankara: İmge Kitabevi.

International Organization for Migration (2004), Essentials of Migration Management, Volume One: Migration Management Foundation: Migration and History, International Organization for Migration, 
Switzerland. http://www.rcmvs.org/documentos/IOM_EMM/v1/volume1.html, (Erişim Tarihi: 10.2.2015).

İçduygu, Ahmet, Sema Erder ve Ömer Faruk Gençkaya (2014), Türkiye'nin Uluslararası Göç Politikaları 1923-2023:Ulus Devlet Oluşumundan Ulus Devlet Ötesi Dönüşümlere, MireKoç Raporları, İstanbul: Koç Üniversitesi Koç Araştırmaları Merkezi.

İçduygu, Ahmet (2014), "Bir Siyaset Siyasa Alanı Olarak Son Yüzyılda Göç: Son Yüzyılda Dünya ve Türkiye”, Türkiye’nin Uluslararası Göç Politikaları 1923-2023: Ulus Devlet Oluşumundan Ulus Devlet Ötesi Dönüşümlere, MireKoç Raporları, (Ed. Ahmet İçduygu, Sema Erder ve Ö. Faruk Gençkaya), İstanbul: Koç Üniversitesi Koç Araştırmaları Merkezi, ss. 26-76.

İçduygu, Ahmet, Sert, Deniz, Karaçay, Ayşem Biriz (2009), Türkiye’ye Yönelen Göç ve Sığınma Hareketleri ve Politikaları Üzerine Brifing, İstanbul: Koç Üniversitesi Göç Araştırmaları Programı, No:1. Kalkınma Bakanlığı (2014), Onuncu Kalkınma Planı 2014-2018 GöçÖzel İhtisas Komisyonu Raporu, Ankara: Kalkınma Bakanlığı.

Katseli, T. Louka and Others (2006), Effects Of Migration On Sending Countries: What Do We Know? Paris: OECD Development Centre Working Paper No:250.

Kirişçi, Kemal (2003), Turkey: A Transformation from Emigration to Immigration, http://www.migrationpolicy.org/article/turkey-transformation-emigration-immigration, (Erişim Tarihi: 12.2.2015).

Kirişçi, Kemal (1999), “Türkiye’ye Yönelik Göç Hareketlerinin Değerlendirilmesi”, Bilanço 1923-1998: Türkiye Cumhuriyeti’nin 75 Yllına Toplu Bakış, Volume 1, (Ed. Z. Bora), İstanbul: Tarih Vakfı Yayınlar1, ss. 111-121.

Laczko, Frank and A. Rudolf (2013), "Introduction", World Migration Report 2013, (Ed. Frank Laczko and Gervais Appave), Switzerland: International Organization for Migration Press. 
Murat, Sedat ve Taşkesenlioğlu, Zehra (2009), Avrupa Birliği Düzeyinde Göç, Entegrasyon ve Yerel Yönetimler, Zeytinburnu Belediyesi Kültür Yayınları 14, İstanbul: Akol Ajans.

National Geographic, (2015), "Human Migration Guide", http://www. nationalgeographic.com/xpeditions/lessons/09/g35/migrationguidestudent.pdf, (Erişim Tarihi: 20.03.2015).

Okutan, M. Çağatay (2009), Tek Parti Döneminde Azınlık Politikaları, İstanbul: Bilgi Üniversitesi Yayınları.

ORSAM ve TESEV (2015), Suriyeli Siğınmacıların Türkiye'ye Etkileri, Rapor No 195, Ankara: ORSAM ve TESEV Yayını.

ORSAM (2012), Küresel Göç ve Avrupa Birliği ile Türkiye’nin Göç Politikalarının Gelişimi, Ankara: ORSAM ve Black Sea International.

Özçürümez, Saime ve Türkay Şirin (2011), “Türkiye’de İltica Politikası, Aktörleri ve Çalışmaları: Bir "Epistemik Topluluk" Oluşurken”, Illtica, Uluslararası Göç ve Vatansızlık: Kuram, Gözlem ve Politika, (Ed. Özlen Çelebi, Saime Özçürümez ve Şirin Türkay), Ankara: Birleşmiş Milletler Mülteciler Yüksek Komiserliği Yayını, ss. 27-48.

Tapia, Stephane (2006), Towards a Migration Management Strategy Cahallenges for Country of Origin, Strasbourg: Council of Europe (The European Committee on Migration).

Tolay, Juliette (2014), The EU and Turkey's Asylum Policies in Light of the Syrian Crisis, Policy Brief 10, http://www.iai.it/en/pubblicazioni/eu-and-turkeys-asylum-policy-light-syrian-crisis, (Erişim Tarihi: 18.3.2015).

Tolay, Juliette (2011), “Türkiye’ de Mültecilere Yönelik Söylemler ve Söylemlerin Politikalara Etkisi,", İltica, Uluslararası Göç ve Vatansızlık: Kuram, Gözlem ve Politika, (Ed. Özlen Çelebi, Saime Özçürümez ve Şirin Türkay), Ankara: Birleşmiş Milletler Mülteciler Yüksek Komiserliği Yayını, ss. 201-213.

UNHCR, BM Mülteciler Yüksek Komiserliği, http://www.unhcr.org/pages/49c3646cbc.html, (Erişim Tarihi: 10.2.2015). 
Zanker, Jessica Hagen (2011), Why Do People Migrate? A Review of Theoretical Literature, Munich Personel RePEec Archive, http://mpra. ub.uni-muenchen.de/28197/, (Erişim Tarihi: 10.3.2015).

Ziya, Olcay (2012), "Mülteci-Göçmen Belirsizliğinde İklim Mültecileri”, TBB Dergisi, Say1 99, ss. 229-240.

5216 Sayılı Büyükşehir Belediye Kanunu.

5302 Sayılı İl Özel İdareleri Kanunu.

5393 Sayılı Belediye Kanunu.

6458 Sayılı Yabancılar ve Uluslararası Koruma Kanunu.

Abstract: -Trans-Border Migration Policies and Administration of Turkey- This study outlined Turkey's international migration policy and administration of migration. This study primarily starts with conceptual presentation. After that the migration in the world and administration of migration is discussed mainly. Later, the immigration policy and the factors that affect the transformation of this policy is discussed in Turkey. In addition, the immigration policy that has been distinguished because of the excessive and irregular migrations over the last thirty years and the institutions that shape this policy and the duties and authorities of these institutions are discussed. The legal regulations that Turkey made for this purpose are analyzed on the basis of national and international concept. The institutional structures are analyzed on two levels, central and local. The roles of the local administrations have also been revised under the title of institutional structures. The study is prepared with a descriptive method of the analysis of the process based on the related literature.

Key words: Turkey, Migration, Migration administration, Migration policies 